

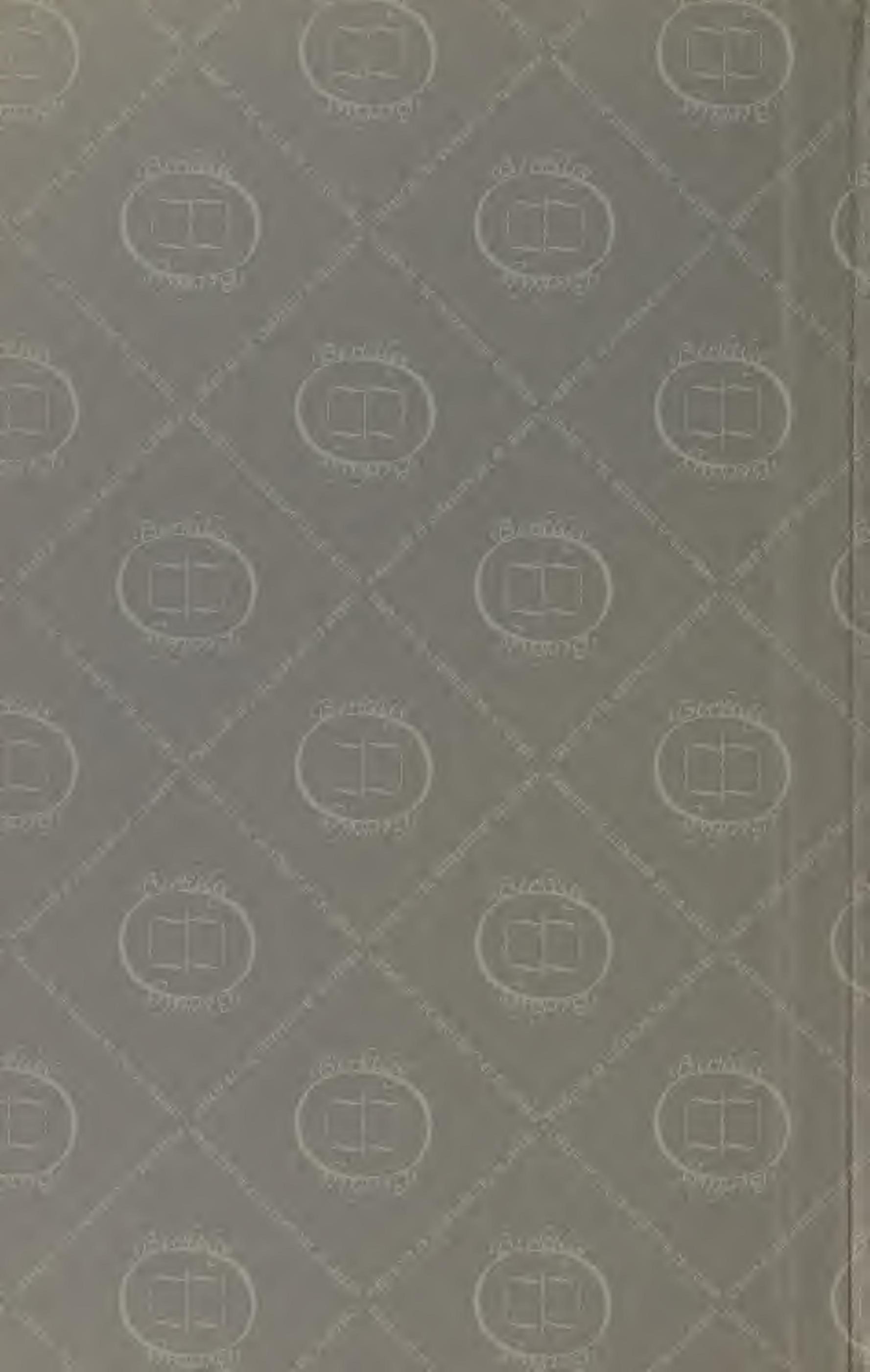




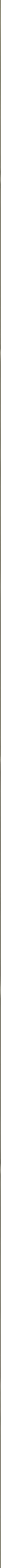




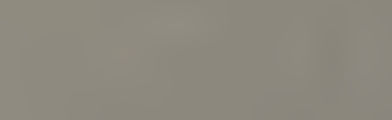 \\ 군}

$-11$

$\sqrt{1}+$

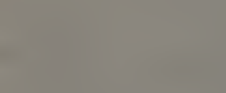

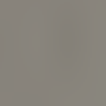

$\mid$

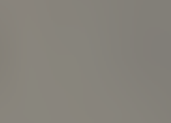

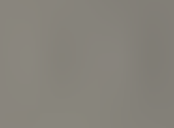

1

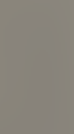


Digitized by the Internet Archive in 2008 with funding from Microsoft Corporation 



\section{THE DECENNIAL PUBLICATIONS OF THE UNIVERSITY OF CHICAGO}




\section{THE DECENNIAL PUBLICATIONS}

ISSSUED IN COMMEMORATION OF THE COMPLETION OF THE FIRST TEN YEARS OF THE UNIVERSITY'S EXISTENCE

AUTHORIZED BY THE BOARD OF TRUSTEES ON THE RECOMMENDATION OF THE PRESIDENT AND SENATE

EDITED BY A COMMITTEE APPOINTED BY THE SENATE

EDWARD CAPPS

STARR WILLARD CETTING

ROLLIN D. SALISBERY

JAMES ROWLAND ANGELL

CARL DARLING BUCK

WILLIAM I. THOMAS

SHAILER MATHEWS

JULIUS STIEGLITZ

FREDERIC IVES CARPENTEP OSKAR BOLZA

JACQUES LOEB 
THESE VOLUMES ARE DEDICATED

TO THE MEN AND WOMEN

OF OUR TIME AND COUNTRY WHO BY WISE AND GENEROUS GIVING

HAVE ENCOURAGED THE SEARCH AFTER TRUTH

IN ALL DEPARTMENTS OF KNOWLEDGE 



\section{INVESTIGATIONS}





\section{INVESTIGATIONS REPRESENTING THE DEPARTMENTS}

\section{ZOÖLOGY ANATOMY PHYSIOLOGY NEUROLOGY BO'TANY PA'THOLOGY BAC'TERIOLOGY}

THE DECENNIAL PUBLICATIONS

FIRST SERIES VOLUME $\mathrm{X}$

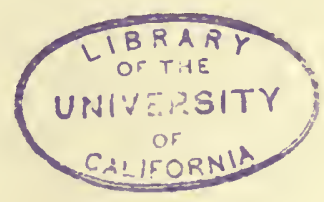

CHICAGO

THE UNIVERSITY OF CHICAGO PRESS 1903 
Copyright 1903

BY THE UNIVERSITY OF CHICAGO 


\section{CON'TEN'TS}

I. On the Production and Suppression of Muscular Twitchings and Hypersensitiveness of the Skin by Electrolytes - - -

By Jacques Loeb, Professor and Head of the Department of Physiology

II. On a Formula for Determining the Weight of the Central Nervous System of the Frog from the Weight and Length of

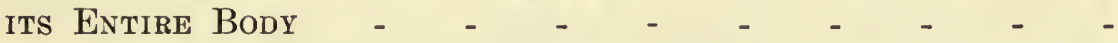

By Henry H. Donaldson, Professor and Head of the Department of Neurology

III. The Development of the Colors and Color Patterns of Coleoptera, with Observations upon the Development of Color in Other Orders of Insects (with Plates I-III) - - -

By William Lawrexce Tower, Assistant in Embryology

IV. The Artificial Production of Spores in Monas by a Reduction OF the Temperature

By Arthur W. Greelex, Assistant in Physiology

V. The Self-Purification of Streams

By Edwin Oakes Jordan, Associate Professor of Bacteriology

VI. The Lecithans: Their Function in the Life of the Cell

By Waldemar Koch, Assistant in Pharmacology

ViI. A Contribution to the Physical Analysis of the Phenomena of Absorption of Liquids by Animal Tissues

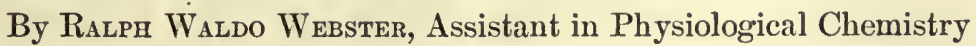

ViII. The Distribution of Blood-Vessels in the Labyrinth of the Ear OF'Sus Scrofa Domesticus (with Plates V-XII) - - -

By George E. Shambaugh, Instructor in Anatomy of the Ear, Nose, and Throat 
IX. The Animal Ecology of the Cold Spring Sand Spit, with Remarks

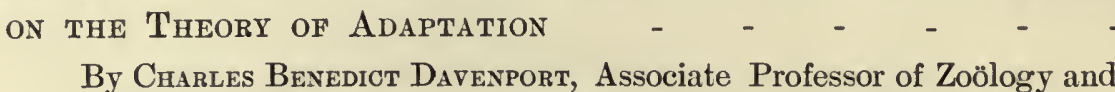
Embryology

X. The Finer Structure of the Neurones in the Nervous System of the White Rat (with Plates XIII, XIV) - _ _ _ $\quad$ - 177 By Shinkishi Hatai, Research Assistant in Neurology

XI. The Phylogeny of Angiosperns

By John Merle Coulter, Professor and Head of the Department of Botany

XII. Studies in Fat Necrosis 155

By H. Gideos Wells, Instructor in Pathology

XIII. Oogenesis in Saprolegnia (with Plates XV, XVI)

By Bradley Moore Davis, Assistant Professor of Botany [Hull Botamical Laboratory]

XIV. The Early Development of Lepidosteus Osseus (with Plates

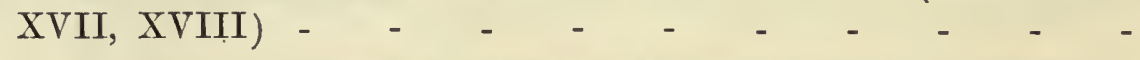

By Albert Chauncey Ercleshymer, Assistant Professor of Anatomy

XV. The Structure of the Glands of Brunner (with Plates XIX-

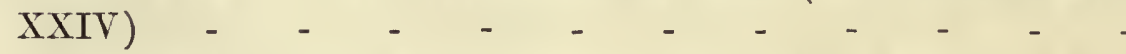

By Robert Rossell Bensley, Assistant Professor of Anatomy

XVI. Mitosis in Pellia (with Plates XXV-XXVII)

By Charles Joseph Chamberlain, Instructor in Morphology and Cytology

XVII. A Description of the Brains and Spinal Cord of Two Brothers Dead of Hereditary Ataxia. (Cases XViII and XX of the Series in the Family Described by Dr. Sanger Brown); (with plates XXVIII-XXXIX) - $\quad$ - $\quad$ - $\quad$ - $\quad$ - $\quad$ - $\quad$ -

By Lewellys Franklin Barker, Professor and Head of the Department of Anatomy. With an Introduction by Dr. SANger Brown 
OOGENESIS IN SAPROLEGNIA 



\title{
OOGENESIS IN SAPROLEGNIA
}

\author{
BradeEy Moore Davis
}

Although Saprolegnia is a form of considerable interest in connection with the problem of the so-called multinucleate gametes, nevertheless investigations have not been carried forward upon it with that attention to cytological detail that has recently been given to other Phycomycetes, e.g., Albugo, Peronospora, Pythium and Sclerospora.

The present paper deals chiefly with the events of oogenesis and a comparison of this process with the development of zoospores. The material employed was apogamous, indeed apandrous, for specimens were chosen entirely free from antheridia to the end that the investigation might be relieved from the dispute on the sexuality of these fungi. However, as will be seen, the results have an important bearing on the wellknown binucleate eggs, assumed by Trow to be stages of fertilization. At the end of the paper will be found an account, entitled "Theoretical Considerations," which deals with a number of topies suggested by this study in relation to recent investigations upon Phycomycetes and Ascomycetes.

The material was isolated in pure cultures and cultivated for several months on various substrata, during which time the writer had the opportunity of observing and confirming many of the adaptations recorded by Klebs (1899) in his detailed study of Saprolegnia mixta. In this period a number of structural peculiarities appeared, associated with the various sorts of nutrition, and forms arose presenting the characters of three closely related species, Saprolegnia mixta, S. monoica, and S. ferax. The variation was most marked in respect to the presence, absence, or relative quantity of antheridia which are the most important distinguishing marks of these species.

The original collection bore oogonia with relatively few antheridia (Saprolegnia mixta), and frequently none. By cultivating the form on a rich substratum - raw beef or fresh insects - a much more extensive growth of antheridial filaments was obtained, as in Saprolegnia monoica. On other media-boiled whites and yolks of eggs and dried beef - the filaments never produced antheridia, but oogonia were formed abundantly (as in Saprolegnia ferax), normal in size and with numerous oospores. After three months all cultures ceased to develop antheridia and the number of oogonia steadily decreased until the cultures reproduced entirely by zoospores.

But it was always possible to get oospores, as Klebs (1899) has shown, by placing cultures developing zoosporangia under such conditions that the hyphæ were no longer submerged. This may readily be done by removing material from water and placing it in a dish of cold agar-agar which will furnish enough moisture to support the fungus for several weeks. The filaments out of water promptly developed oogonia, 
even when they had the form characteristic of zoosporangia. Such cultures frequently showed club-shaped oogonia whose eggs were arranged approximutely in a line.

Chromacetic acid proved to be the most satisfactory fixing agent, but it must be employed much weaker than the usual formula. One per cent. chromacetic acid caused immediate contraction of the protoplasm, but a solution one-fourth per cent. chromic and one-tenth per cent. acetic acid gave excellent results, and presented advantages of clearness and preservation over weak Fleming, Merkel, corrosive sublimate, sublimate acetic, iridium chloride, or picric acid. Paraffin sections were cut 3-5 $\mu$ thick, and generally stained with safranin and gentian violet. The protoplasmic structures are so minute as to require lenses of the clearest definition, and the Zeiss apochromatic objectives $2 \mathrm{~mm}$. and $1.5 \mathrm{~mm}$. with the compensating oculars were employed throughout the investigation.

\section{OOGENESIS}

The accounts of nuclear and cytoplasmic activities in Saprolegnia during oogenesis present some striking contradictions, and leave untouched some phases of a detailed but very significant character. Humphrey (1892) was the first author to apply methods of cytological technique, cutting sections in paraffin, and his studies were followed by the investigations of Trow $(1895,1899)$ and Hartog $(1895,1896,1899)$. The last two authors have expressed very divergent views, asserted with a positiveness that invests their discussions with an atmosphere of personal criticism that need not be reviewed in this paper. It is necessary, however, to consider certain conclusions of the earlier authors with which the present writer cannot accord, and it seems best to do this at the outset, leaving the points of agreement with the present investigation to be taken up in their proper connections.

It is well known that the oogonium of the Saprolegniales contains many times more nuclei than the number of eggs ultimately formed. Humphrey and Hartog believed that the nuclei fuse with one another, thus reducing the sum total until the requisite number was present. Trow stated that the number was diminished through degeneration and digestion until it was so small that each egg took but a single nucleus. The writer has found no evidence of nuclear fusions as reported by Humphrey and Hartog, and in general supports Trow's view of degeneration. However, there seems to be a reason, not known to Trow, for the selection of the fortunate nuclei destined to preside over the eggs, and a large part of this paper will deal with that matter.

It is also well known that the eggs of the Saprolegniales are not infrequently binucleate and sometimes trinucleate. Humphrey and Hartog considered such conditions as merely the final stages in that process of general nuclear fusion, the last pairings whereby the eggs become uninucleate. Trow has made much of these binucleate eggrs, believing the two nuclei to be sexual and one of them introduced by an antheridial filament. He has been bold enough to assert sexuality for four members of the 
group: Saprolegnia declina, S. mixta, Achlya Americana, and A. Americana var. cambrica. Nevertheless, Trow presents very little evidence that the so-called "male" nucleus comes from the antheridial tube, or that the latter structure ever opens into the eggs. The writer cannot justify Trow's conclusions in this matter, believing them premature as to evidence and illogical as to probabilities. The present study will attempt to show that binucleate and trinucleate eggs are to be expected under the peculiar conditions governing oogenesis.

With respect to cytological details, investigations scattered over so long a period as twelve years could hardly be expected to agree. Hartog studied from entire mounts, yet was able to count chromosomes and observe nuclear figures. Trow sectioned in paraffin, and was at first (1895) completely deceived as to the interior structure of the nucleus and the number of chromosomes. In his second paper, however, Trow (1899) concedes that the nuclei in the antheridia and oogonia divide mitotically, but his figures are far from clear as to detail. Trow was also mistaken in his interpretation of the nucleolus.

The present study will give a more detailed account of nuclear structure and activities than any previous paper. But the most important contribution relates to certain cytoplasmic manifestations that seem to determine in large part the results of oogenesis. These cytoplasmic activities place the process of oogenesis in Saprolegnia in new light, bringing it into sympathy with conditions in Albugo, Peronospora, and Sclerospora. They are concerned with that cytoplasmic structure termed the cœnocentrum.

It is not strange that Humphrey, Hartog, and Trow failed to find the cœnocentrum, for its recognition demands exceptionally good fixation and staining. It is probable that Dangeard saw it when he described an oil globule or fatty mass in the center of the egg. It seems possible that Trow may have mistaken it at times for a centrally placed nucleus, to which it bears a certain resemblance that might make the two structures indistinguishable in obscurely stained preparations. The cœenocentrum does not appear until the processes of oogenesis are well under way. Previous to this period there are nuclear and cytoplasmic activities of considerable import, and they will be considered first.

It is well known that with the flow of the protoplasm into the swollen tip of a hypha there is apparent that peculiar structure of the protoplasm (Plate XV, Fig. 1) significant of its streaming movement. The nuclei at that time are very small. When the oogonium is cut off by a. septum from the hypha that bears it, the protoplasm becomes distributed almost homogeneously through the interior (Fig. 2). The nuclei then increase in size and shortly after show most clearly that detail of structure that is to be expected in the resting nucleus. This structure agrees with the accounts of Harper, Wagef, Stevens, and myself for the nuclei in other types of fungi, indicating that the conditions among these lower forms are essentially similar to the nuclear structure of higher plants. As is shown in Figs. 3 and 4 and especially in 
Fig. 6 (Plate $\mathrm{XV}$ ), there is a nuclear membrane inclosing a well-differentiated nucleolus, prominent by its size and staining qualities. Much less conspicuous, but readily demonstrated in well-fixed material, is a loose linin network which contains the chromatic material. Trow's description of a central body containing cromatin and nucleolar matter, but "neither a nucleolus nor a chromosome," must have been founded on inferior preparations. There are certainly no complexities in Saprolegnia comparable to the so-called nucleolus of Spirogyra (Mitzkewitsch, 1898, or Wisselingh, 1900).

There is one mitosis in the oogonium, but previous to that event a number of vacuoles are developed which generally result in a peripheral arrangement of the protoplasma around a large central space or vacuole containing cell sap. The vacuoles begin to appear immediately after the oogonium is cut off from the parent hypha (Fig. 2). They grow larger and run together as bubbles do in soapsuds (Fig. 3), until finally there are one or perhaps two large vacuoles in the center, and occasionally smaller ones near the edge (Plate XV, Figs. 10 and 11). The protoplasm then lies as a thick peripheral zone, and the nuclei (Fig. 5) are distributed around at varying distances between the oogonial wall and the boundary of the vacuole.

This is the period when one may expect to find the nuclei in mitosis. The event happens to most nuclei at about the same time, and good preparations of this stage of oogenesis are very striking (Fig. 5). The oogonium will be filled with the diamondshaped spindles inclosed in nuclear membranes. Three stages of mitosis are shown in Figs. 7, 8, and 9. It will be noted that the spindle is intranuclear. Fig. 7 presents the condition just previous to metaphase, with the chromosomes, four in number, at the nuclear plate and the nucleolus lying outside of the spindle. Fig. 8 is of a stage shortly after metaphase, when the two sets of daughter-chromosomes have separated and are about to pass to the poles; the nucleolus is still present, but smaller and staining faintly. Fig. 9 is of anaphase, the two groups of daughter-chromosomes, four in each, lying at the poles of the spindle and the nuclear membrane manifestly about to disappear. The nucleolus probably dissolves, at least I have never been able to follow it much beyond metaphase, but surviving, it would of course soon be lost in the granular cytoplasm after the breaking down of the nuclear membrane. Although granules are sometimes present at the poles of the spindles, the latter are generally entirely free from appearances that might suggest centrosomes.

It will be noted that this description of mitosis in Saprolegnia is similar in all essentials to the accounts of Wager (1896), Stevens $(1899,1901)$, and myself $(1900)$ for Albugo; Wager (1900) for Peronospora; Miyake (1901) and Trow (1901) for Pythium; and Stevens (1902) for Sclerospora. These studies cover a wide range of forms and material. They agree in describing the spindle as always intranuclear and without centrosomes. The nucleolus is a structure always distinct from chromatic material and always, as far as we know, disappearing during mitosis by dissolution or extrusion into the cytoplasm. The chromosomes are derived from a linin network and 
after mitosis the chromatin returns to the granular condition generally present in resting nuclei.

Following the mitosis, the oogonium passes into a condition that is exceedingly difficult to study. The number of nuclei has been doubled by the division, but the daughter-nuclei are much smaller than the parents. A comparison of Fig. 4 with Fig. 10 will illustrate well the change. It is not the small size, however, that makes the examination so difficult, but the fact that these nuclei very shortly show signs of degeneration. Almost all of the nuclei are affected. The nuclear membrane becomes indistinct, and its contents finally lie as granular matter in a clear area that resembles, and probably is, a vacuole. The granular matter is undoubtedly derived in large part from the nucleolus that fragments, but some of it may be chromatin. The study of the steps in this process of general degeneration is especially baffling because the progress is toward a time when the nuclear material becomes indistinguishable from other granules in the cytoplasm.

It is difficult to understand how Humphrey and Hartog could ever have interpreted this process of degeneration as successive nuclear fusions. As Trow pointed out, successive fusions should give more and more conspicuous nuclei, as the material accumulated with each union, and consequently an ever-increasing clearness of conditions. In reality, however, we pass from the stage illustrated by Fig. 10 just after mitosis, to the vague conditions presented in Figs. 11, 14, and 15 (Plate XV). The last two figures are of oogonia much older than those shown in Figs. 10 and 11, and illustrate late stages in the process, when the nuclear membranes have mostly disappeared and the nucleoli and possibly chromatic material lie in vacuoles. Such vacuoles are frequently elongated, and when they contain two masses of deeply staining material there is suggested a stage in nuclear fusion, and such appearances probably deceived Humphrey and Hartog. However, the vagueness of structure and manifest waning of the previous clear definition should have put these observers on their guard. These degenerate nuclei remain for a long time, even after the eggs are fully formed, and it is quite impossible to tell with exactness when they lose their structure and functions.

The eggs are formed during the process of nuclear degeneration described above, and their nuclear structure is really determined by that event. Trow (1899) has given us a very good account of the general stages in this process of protoplasmic segmentation, but he did not know the cytological details, and there is reason to believe that he may have been mistaken in his interpretation of certain structures which he considered nuclei. The first external indication of protoplasmic segmentation is the gathering of the contents of the oogonium into denser masses around certain centers, these masses projecting into the central vacuole and destroying that even outline present in earlier conditions of the oogonium (Fig. 5). The protoplasm between the egg origins is less dense, and presently begins to develop small vacuoles (Fig. 12) which run together until the egg origins are separated by spaces of considerable size (Fig. 13). Many of these vacuoles break through the films of protoplasm into the central space, which 
then appears to have put out extensions toward the cell wall. The protoplasm of the oogonium is exceptionally mobile at this time, and the vacuoles are constantly changing their forms and positions. In the end the protoplasm gathers more and more closely around the centers of the spore origins, and finally the latter break away from one another at all points of mutual contact (Fig. 13), and the several independent protoplasmic masses round themselves off as eggs.

The reader will have noticed in the illustrations of this protoplasmic segmentation that each egg origin has a deeply stained center surrounded by delicate rays (Figs. 12-15). These star-like structures are very conspicuous under low magnification (in Figs. 12 and 13, 500 diameters), when the center appears to be a single structure. In reality it is not a simple unit, but is always composed of at least two structures, a cœnocentrum accompanied by a nucleus. This dual nature is made clear only under high magnification, with clear preparations of very thin sections. I do not think it would be possible to understand the structure from entire mounts such as Hartog's. Hartog probably considered the center as a nucleus alone, and certain of Trow's figures indicate that he gave a similar interpretation. The cœnocentrum is really the key to many of the problems of oogenesis in Saprolegnia.

The cœnocentrum varies in its minute structure with different periods of oogenesis. It is at first a small body composed of several granules imbedded in dense material, from which a number of delicate fibrils radiate into the surrounding cytoplasm. The structure stains deeply and resembles an aster. After the eggs are fully formed the rays disappear and the cœnocentrum grows larger, takes on a spherical form, and resembles a globule of oil or fat. The cœnocentrum finally dissolves, sometimes with fragmentation, and completely disappears in the older eggs. The coenocentrum is then a structure peculiar to that period of oogenesis characterized by nuclear degeneration and the segmentation of the protoplasm to form the eggs. It bears a most important relation to these two events, which are the most difficult to study in the entire process of oogenesis.

We must begin with the first appearance of the cœnocentra. These structures may always be found before the differentiation of the egg origins, at the time when the oogonium is filled with degenerating nuclei. The latter lie scattered through the cytoplasm, as is shown in Figs. 14 and 15, and exhibit varying degrees of dissolution. The young cœnocentra are always found in the densest regions of the protoplasm, portions destined to become egg origins, such as are shown in Figs. 14 and 15. They are very small at first and would scarcely be noticed except for the radiating fibrils that mark their position. They increase in size as the egg origins take more definite form (Fig. 16, Plate XVI).

An examination of Figs. 14, 15, and 16 will show at the side of each cœnocentrum a small nucleus. This structure is very small at early periods of oogenesis (Figs. 14 and 15) and scarcely more clear than many of the degenerating nuclei in the neighborhood. But as oogenesis proceeds the nucleus accompanying the cœnocentrum 
grows larger and increases greatly in staining material (Fig. 16). When the eggs are fully formed this nucleus is many times larger than at the first appearance of the cœenocentrum, as may be seen by comparing Figs. 17-21 (Plate XVI) with Figs. 14 and 15, which are all magnified 1,000 diameters. One would hardly think it possible that the large nucleus present in the center of the mature egg was ever so small as the degenerating nuclei whose remains may be found in advanced stages of oogenesis (Fig. 16), and sometimes even in the fully formed eggs (Figs. 17 and 23). But there seems to be no doubt of this. The nucleus destined to preside over the egg is at first indistinguishable in size or structure from many of its neighbors.

What should lead to its selection as the egg nucleus? I can see no other explanation but that its position gives it dynamic advantages, enabling it to survive when its neighbors lack the metabolic conditions necessary for nuclei and consequently must degenerate. This conceives the oogonium as too richly stocked with nuclei for the metabolic conditions of oogenesis, and in consequence the field of a struggle of the parts ("der Kampf der Theile," Roux).

What is the relation of the coenocentrum to these events? As we have stated, the cœnocentrum is not a permanent organ either in the oogonium or the egg. It appears with the first indications of the egg origins and passes away as the eggs grow older. It is obviously a transitory structure peculiar to the most active periods of oogenesis. To the writer the cœnocentrum seems to be the morphological expression of dynamic activities in the oogonium, and especially in the egr origins at the time when these are differentiated. The cœnocentrum has the appearance of being the focal point in the center of the egg origins of the metabolic conditions peculiar to oogenesis. And this offers a very plausible explanation of the survival of the nucleus which lies nearest the cœnocentrum.

The nucleus most fortunate in its position near the cœnocentrum should be greatly benefited if this is a region of the protoplasm more favorably nourished than other parts. It is probable that the cœnocentrum even draws toward itself nuclei within a certain sphere of attraction. Nuclei may be found with a pointed end extended toward the cœnocentrum (Figs. 16 and 20, Plate XVI). It will be remembered that Stevens (1901, showed with great clearness for Albugo candida and A. Tragopogonis that the nuclei in the immature eggs stretch toward the cœnocentra so that their long dimensions are frequently twice the width. The nuclei of Saprolegnia are too small to present conspicuous morphological evidence of this character. But we have the fact that the favored nucleus is almost always pressed against the cœnocentrum which, together with the appearance of the nuclei and what we know of the events in Albugo, makes it quite certain that the cœnocentrum exerts a chemotactic influence.

The changes that come over the egg as it matures are illustrated in Figs. 16 to 21 (Plate XVI), which show the usual uninucleate condition of the egg. Binucleate and trinucleate eggs will be described in the following paragraphs. The two most important events of maturation are the increase in size of the nucleus and the gradual dissolution 
and final disappearance of the cœnocentrum. The growth of the nucleus involves not only the extent of the space inclosed in the nuclear membrane (Figs. 17-21), but also means a great increase in the amount of staining material, chromatic and nucleolar. The latter must be very many times greater in quantity in old eggs than at the beginning of oogenesis (compare Fig. 16 with Figs. 20 and 21). The cœenocentrum decreases in size until it becomes a very small globule (Fig. 20), or it may split up into several granules, which soon become lost in an ill-defined mass of denser protoplasm. The cœnocentrum finally disappears, and the contents of the egg then arrange themselves around a central vacuole, with the nucleus taking a peripheral position. This is the structure of the mature egg, and is illustrated in Fig. 21.

We will now consider some conditions that have given rise to much discussion, namely, the binucleate and trinucleate eggs. They have been found by Humphrey, Hartog, and Trow, and the present study indicates that they may be expected in any member of the Saprolegniales. Trow attached much significance to them as evidence of sexuality, but his conclusions seem to the writer open to much criticism and will be taken up presently. Figs. 22-5 (Plate XVI) illustrate several conditions that show how easily an egg may become binucleate. Suppose two nuclei lie near enough to the cœnocentrum to share about equally the advantages of position. Then it is not likely that either will give way to the other. Such conditions in a young egg are shown in Fig. 22. Fig. 25 represents also a pair of nuclei one above the other and both extended toward the cœnocentrum, which was fast breaking down. Fig. 24 is very interesting. In this instance the cœnocentrum is the center of a mass of protoplasm considerably larger than the average egg. There are two well-developed nuclei, and the form of the cell suggests the probability that material which ordinarily would have gone into two eggorigins has been held together in this instance by the influence of an especially large cœnocentrum. An illustration of quite the reverse condition is shown in Fig. 23, and is remarkable. Here we have presented an egg with two cœnocentra, and at the side of each a nucleus. There is no doubt from the age of the eggs that the two nuclei in each of these cases are sister nuclei. It is plain that the processes that work for the segmentation of the protoplasm in the oogonium are complex, not all in the influence of the cœnocentrum, nor yet all in the general activities of the cytoplasm.

Give the egg two nuclei with a fair start over their degenerating neighbors, and they seem to be able to exist side by side, not differing, as far as one may see, from the nuclei of uninucleate eggs. The two nuclei may lie far apart, as in Fig 26, or so near together that they touch, as in Figs. 25 and 27. But in no instance - and I have seen a great many binucleate eggs - have I ever observed them fusing. Trow (1899) reported an instance of nuclear fusion in the egg, but the writer thinks we are justified in waiting for confirmations of this observation before attaching to it the importance given by that author.

Trinucleate eggs are somewhat rare in Saprolegnia mixta. I have seen hardly more than a dozen, and these were all rather mature examples. I have never been for- 
tunate enough to find young stages, periods comparable to Fig. 22, 23, or 24 of the binucleate eggs. The three nuclei may be grouped close together in the egg (Fig. 28), or may lie quite separate from one another (Fig. 29). There is no evidence that they fuse. . The rather meager data at hand indicate that when there are three nuclei in an egg they are individually smaller than the single nucleus in an ordinary egg (compare Figs. 28 and 29 with Figs. 19-21). This is to be expected, for in general the three nuclei share between them the metabolic possibilities of about the same amount of protoplasm as is in the uninucleate egg. The trinucleate egg probably develops, as does the binucleate, from an egg origin in which more than one nucleus by fortunate position is able to survive the processes of general degeneration.

Let us now examine Trow's position respecting sexuality in the Saprolegniales. They are presented most completely in his 1899 paper. I approach this subject with some diffidence, for it has already been the occasion of detailed discussions of a personal character (Hartog, 1896, 1899). The matter finally boils down to a question of confidence in Trow's evidence, his account, and his figures. Everyone must admit the possibility of sexuality in the Saprolegniales, but the question for us is: Does Trow prove it?

The binucleate egg gave Trow the conviction, as he acknowledges, that fertilization took place through the introduction of a male nucleus into the egg from an antheridial tube. But the present studies show that binucleate eggs are quite common in an undoubted apogamous form, the material being entirely free from antheridial filaments. Moreover, these binucleate eggs have been followed through younger stages back almost to the period of the egg origins, and we know that these two nuclei were sisters in the oogonium. To make this point more plain, let the reader contrast the appearance of the two small nuclei shown in Figss. 22 and 23 with the nuclei in older eggs (Figs. 19, 20, and 21) and it will be evident that the former have the size and structure of nuclei in the young oogonium, and not of the fully mature gamete (egg) nucleus. It should also be noted that Hartog's binucleate eggs were from apogamous material (Hartog, 1898 and 1899, p. 450) as were also mine.

If, then, apogamous material may have binucleate eggs, and the events of oogenesis explain the conditions, we are justified in examining Trow's evidence of sexuality very critically and demanding of it exceptional fulness and accuracy. We are concerned chiefly with Trow's figures, for they should show most exactly what the investigator really saw. I have been impressed with the lack of detail in many of these figures, which has led me to think that Trow may have made a number of mistakes which would quite invalidate his evidence in support of sexuality. Figs. 43, 44, and 46 (Plate XVI) give appearances labeled "female gameto-nuclei" which are very similar to cœenocentra, and I fear that he was not able to separate these structures in his preparations. Fig. 35 certainly indicates that his material had cœnocentra. But the most serious difficulties are encountered in his drawings of male gameto-nuclei (Figs. 45 and 46). These are not clear enough to be convincing; indeed, they seem to the writer to be the remains 
of degenerating nuclei at the periphery of the egg. Side by side with the structures labeled "male gameto-nuclei" Trow figures bodies very similar in appearance, which are probably degenerate nuclei. In the face of this uncertainty and seeming contradiction of evidence the illustration of an antheridial filament piercing the egg (Trow, 1899, Fig. 45) loses much of its weight, and the statement that two nuclei fuse in the center of the egg (Trow, 1899, Fig. 47) is open to much doubt. The subject is so difficult that there are abundant opportunities for error, and we are justified in asking for much more evidence before accepting such important conclusions.

The writer cannot better sum up his attitude toward Trow's opinions on sexuality in the Saprolegniales than by defining them as not proven and improbable in the face of the mass of observations upon which botanists have generally agreed that the group is apogamous. The view of apogamy, formerly resting entirely on the failure to find antheridial tubes fusing with the eggs, is now supported by the present investigation on the details of oogenesis. These show that the binucleate egg, formerly difficult to understand on the theory of apogamy, may arise very naturally in a multinucleate oogonium when the method of oogenesis is as just described for Saprolegnia mixta.

The binucleate and trinucleate eggs of Saprolegnia are essentially similar to the multinucleate eggs of Albugo Bliti and A. Portulacae, and the conditions in the young eggs of $A$. candida and $A$. Tragopogonis, as described by Stevens (1899-1901). These latter, it will be remembered, contain several potential gamete nuclei, but, so far as we know, only one of these becomes functional. But it would not be surprising to find at any time binucleate or trinucleate eggs among species of Albugo that are normally uninucleate.

In concluding, we must lay emphasis on the importance of the cœnocentrum as an index of the activities peculiar to oogenesis in Albugo, Peronospora, Sclerospora, Pythium, and Saprolegnia. Although this structure is probably in large part the expression of activities of the protoplasm as a whole, still there can be no doubt of its material existence. It is difficult to understand how Trow (1901, p. 291) can question this point, except that his figures indicate that fine details of structure were not shown in his preparations.

It would be strange, indeed, if so large a mass of protoplasm as the cœenocentrum should not react in turn on the protoplasm that gave it birth. The cœnocentrum is not a mass of food material, even though much of its granular substance may be the products of metabolism, and the structure as a whole trophoplasmic in character. It is protoplasm, and as such must be counted a factor in the subtle processes of oogenesis. Trow's comparison of the cœenocentrum to a whirlpool in a river is not good, for there is unquestionably in this structure the expression of chemical phenomena as well as physical. The evidence is very strong from Stevens's (1901) work on Albugo, and the present study on Saprolegnia, that the cœnocentrum has a sphere of chemotactic influence on the nuclei in its neighborhood. 


\section{SPOROGENESIS}

Except for a recent paper by Timberlake (1902) on Hydrodictyon, we know little of the details of zoospore formation in either algæ or fungi, and the field would certainly repay investigation. The writer examined the sporangium of Saprolegnia mixta to contrast the conditions there with the processes of oogenesis, but little came of the study, the subject not being favorable, except a general confirmation of the accounts of sporogenesis given by Rothert (1888), Hartog (1888), and Humphrey (1892). If the oogonium is the homologue of the sporangium, we should expect a general similarity in the protoplasmic activities of each structure. There is the general agreement that the protoplasm segments by cleavage planes determined chiefly by vacuoles. But beyond this the activities of the two structures have little in common and a great many peculiarities.

As is well known; there is no mitosis in the sporangium. A large number of nuclei are carried into the tip of the hypha by the accumulation of protoplasm there. Vacuoles collect and develop in the center of the young sporangium (Fig. 30, Plate XVI), and, flowing together, form a large central space inclosed in a vacuolar membrane (Fig. 31). The nuclei then lie scattered in the peripheral layer of protoplasm, and presently clefts appear which work outward between the nuclei from the central vacuole (Fig. 32). The clefts divide the protoplasm so that it is cut up into polygonal areas, with clearer regions between. These are the zoospore origins, and each contains a nucleus.

Rothert's explanations of succeeding conditions, which have also been confirmed by Humphrey and Hartog, seem entirely satisfactory. The sporangium is in a state of turgor when the clefts arise and push their way from the central vacuole toward the periphery. They finally reach the cell wall and immediately make possible the relief of the fluid in the central vacuole. There is at once a very evident decrease in turgor, which has an interesting effect on the appearance of the spore origins. The polygonal areas run together, and the whole sporangium becomes again almost homogeneous in structure. This means that the contraction of the sporangium brings the spore origins so close together that the clefts become almost obliterated. The spore origins also swell. They then begin slowly to separate preliminary to their final rounding off as zoospores. There is a period when the small masses of protoplasm form a very irregular network throngh the sporangium (Fig. 33), and this is followed by a more regular arrangement (Fig. 34), in which the spore origins are connected by very delicate protoplasmic strands. The latter are finally broken and the bodies round off as zoospores.

The writer searched persistently in the sporangium for cytoplasmic centers around which the process of segmentation might proceed, in the hope that light would be thrown upon the problem of the cœnocentrum, but the examination brought forth no evidence of sich structures in the sporangium. The nuclei themselves seem to be the ultimate centers of segmentation. The cœnocentrum is then, so far as we know, a structure peculiar to the oogonium. 


\section{THEORETICAL CONSIDERATIONS}

The writer has once before (Davis, 1900) treated a number of topics suggested by recent studies on the Phycomycetes. The advances in this field of research, and also among the Ascomycetes, have been significant, and we seem to be nearing a point where much clearer conceptions of morphology and phylogeny may result. In this paper we will take up a number of considerations suggested by this and other investigations since 1900, and for convenience they will be grouped under headings as follows:

1. Homologies of the cœnogamete.

2. Origin and evolution of the cœnogamete.

3. Pyronema and cœnogametes among the Ascomycetes.

4. Phylogeny of Phycomycetes and Ascomycetes.

5. The nucleus of Phycomycetes in ontogeny.

\section{- HOMOLOGIES OF THE CGNOGAMETE}

The writer suggested the term "cœnogamete" (Davis, 1900) as appropriate to fusing multinucleate masses of protoplasm whose individual nuclei are actually or potentially sexual. Stevens's first paper (1899) on Albugo Bliti really opened the field in its newer cytological aspects. Since then Harper (1900) has described for the Ascomycete Pyronema strikingly similar conditions, as has Juel (1902) for Dipodascus; and from the studies of Gruber (1901) we know more about the sexual processes in the Mucorales. Harper's results will be considered in a special connection. It is important at the outset that we understand clearly the homologies of the coenogamete.

Are all cœnogametes homologous with one another, and from what have they been derived among the algæ? It will be agreed that the Mucorales, Albugo Bliti, and Pyronema illustrate completely the conception of a cœnogamete. It is part of our problem to determine the relation of these conditions to the sexual organs in other species of Albugo, and in Peronospora, Pythium, and the Saprolegniales. There may be some hesitancy in following the series of homologies that the writer shall propose, and the evolutionary history to be suggested, but he can see only two possibilities, and one of these so obscure that it seems almost impossible in the light of our present knowledge, incomplete as it is.

The most important structures in the cœnogamete are the nuclei, and there can hardly be any question but that they individually stand for energids that among the algæ are independent uninucleate gametes. Stevens's (1899) term "compound oosphere" expressed very well this conception of the conditions in Albugo Bliti. It was employed when this form was the only type known presenting the structure implied by the phrase, and these conditions might have been purely exceptional. But we now know from later studies of Stevens (1901) that other species of Albugo (A. Portulacae, A. Tragopogonis, and $A$. candida) have phases of ontogeny identical with the essential periods of oogenesis in $A$. Bliti, and may be brought into very intimate relation to the latter species. We also know that the cœnogamete is not 
restricted to the Peronosporales, but is characteristic of the Mucorales, and is found also among the Ascomycetes. It is not likely that we shall retain the phrase "compound oosphere," for a broader conception will probably take its place, but a purpose has been served and a field opened to investigation that was quite undreamed of by the earlier investigators of the Phycomycetes.

The nuclei of cœnogametes are homologous with nuclei in a gametangium destined to develop independent sexual cells. Hartog's (1891) conception of the nuclei in the periplasm of Peronospora as representing degenerate gametes has been completely justified, and there are very good reasons for believing that the nuclear divisions in the oogonium and antheridium of the Saprolegniales and Peronosporales are "phylogenetic reminiscences of the formation of gametes." The attempts to establish special functions for these mitoses as reduction divisions for the eggs have been inconclusive.

The oogonia and the antheridia of the Peronosporales, Saprolegniales, and Pyronema are the homologues of gametangia, and consequently of that simplest type of cœnogamete, as illustrated in the Mucorales. There is everything in the morphology of these structures to favor these conclusions, but only recently have we known the details of protoplasmic organization. When an entire gametangium functions as a gamete, as in the Mucorales, it becomes a conogamete. In Pyronema, Albugo, and the multinucleate eggs of the Saprolegniales the cœnogametes are restricted portions of the protoplasm in such gametangia, but it is obvious that in Pyronema and Albugo the gametangium behaves as a whole in a manner strictly similar to the fusion of the cœnogametes in the Mucorales. It should be noted that these homologies are quite independent of the problem of the origin of the cœnogametes in the various groups. That topic will be treated in the next section of the paper.

Stevens (1901) has carried the homologies a step farther in suggesting that the receptive papilla from the oogonium of the Peronosporales marks the position of the pore that develops in the gametangia of alga to give entrance or exit to the sexual elements. This is a very interesting comparison and is worth following to its limits. Thus the points of fusion of the cœenogametes of a mould may be homologous with the points of exit of the motile gametes from the gametangium of some algal ancestor.

The term "cœenogamete" should be employed in the strict sense indicated when the term was proposed (Davis, 1900, p. 307). It is a structure containing more than one gamete nucleus, and generally very many functional or potential gamete nuclei. It is generally homologous with a gametangium, the binucleate and trinucleate eggs of the Saprolegniales, and the multinucleate eggs of Sphaeroplea connulina var. Braunii (Klebahn, 1899) presenting the only exceptions, for the oogonia of Albugo Bliti, A. Portulacae, and $A$. Tragopogonis really acts as a whole, and it is hardly possible to separate in these forms the cœnogametes (oospheres) from the gametangia. When we say that the oogonium of Albugo, Peronospora, Sclerospora, and Pythium acts as a whole we mean that the periplasm is not to be considered as waste material, but as a specialized region of the cell, with important functions in relation to the eggs, which 
it helps to protect by assisting in the formation of heavy walls. The Mucorales, Pyronema, and these three species of Albugo furnish the best known illustrations of cœnogametes.

\section{ORIGIN AND EVOLUTION OF THE CCENOGAMETE}

There seem to be only two possible sources of the cœnogamete. It is conceivable that a uninucleate sexual element might become multinucleate, perhaps through such an increase in the protoplasmic content that more than one nucleus would be required to control satisfactorily its activities. The second possibility is an origin from a multinucleate gametangium that has given up the production of uninucleate gametes, and acting as a unit becomes itself a sexual organ, a cœnogamete. Such an evolutionary process would find its analogy in those sporangia (conidia) of certain species of Pythium and Peronospora, which now germinate as a whole (by a tube) instead of forming zoospores.

The first possibility has absolutely no evidence in its support. There is no series of forms whose sexual cells pass from a uninucleate condition to a multinucleate. There are no indications that such an evolutionary process has ever taken place among plants. There are only two instances known where eggs, free from periplasm, are multinucleate. The eggs of Albugo are so intimately associated with periplasm that they cannot be considered apart from the gametangium in which they lie. These two examples are the binucleate and trinucleate eggs of the Saprolegniales and the multinucleate eggs of Sphaeroplea anmulina var. Braunii. Our investigations of Saprolegnia have shown that the processes of oogenesis in that group have as an end the sacrifice rather than the preservation of nuclei, and the uninucleate condition is evidently the goal of evolution. Klebahn's (1899) and Golenkin's (1899) studies of Sphæroplea are incomplete in certain cytological details of oogenesis, and the fact that the eggs of some forms are uninucleate suggests caution before laying emphasis on the multinucleate condition. It is possible that further study will relate the multinucleate eggs to the uninucleate, as in Saprolegnia.

What evidence have we of the second possibility, $i . e$., the origin of the cœnogamete from a multinucleate gametangium which, ceasing to form uninucleate sexual cells, becomes itself a cœnocytic gamete? Most important is the exceedingly interesting series of four species of Albugo described with so much detail by Stevens (1901). We cannot take up this investigation except to notice that the four species form a wellgraded series in which the evolutionary direction is clear and very important for the conclusions that we are striving to establish. The oospheres of Albugo Bliti and $A$. Portulacae contain many functional gamete nuclei, that of $A$. Tragopogonis several potential and several functional, and that of $A$. candida several potential and one functional. In this series the cœenocentrum is very small in A. Bliti and A. Portulacae, larger in $A$. Tragopogonis, and very large and strongly chemotactic in $A$. candida. A fifth form has been added to this series by Ruhland (1902), who finds that Albugo Lepigoni is even more highly specialized than Albugo candida, since it contains an 
extraordinarily large coenocentrum. The evolution in complexity is plainly from $A$. Bliti to $A$. candida and A. Lepigoni, that is, from the multinucleate egg to the uninucleate. And this series offers the most striking evidence against the evolutionary possibility considered in the previous paragraph.

Now, the multinucleate eggs of Albugo are not the most primitive types of cœnogametes, because they contain only a portion of the total number of nuclei in the gametangium, many of the sister-nuclei passing into the periplasm. They are not as simple as the cœnogametes of the Mucorales, nor yet as primitive as the oogonium of Pyronema, which has no periplasm, although it sacrifices a large number of nuclei in the conjugating tube (trichogyne), and by this specialization presents conditions more complex than the molds.

It is the specialization of a periplasm simultaneous with the reduction in the number of functional gamete nuclei that has made possible the elaborately organized oogonium of Peronospora, Sclerospora, Albugo, Araiospora, and to a lesser degree Pythium. And the cœnocentrum is perhaps most largely responsible for the highest degree of specialization. The cœnocentrum largely influences and perhaps controls the position and structure of the eggs. The larger the cœnocentrum, the more direct is the effect on neighboring nuclei, and the greater is the benefit to such nuclei as are fortunate to be within its sphere of operations. So in the struggle for existence among potential gamete nuclei in the oogonium, the cœenocentrum has a power of assistance that, according to its degree of development, determines the structure of the egg, whether multinucleate or uninucleate. The evolutionary trend is physiologically precisely the same as is shown among the algæ (Fucales, Vaucheria), when potential gamete nuclei are sacrificed to provide functional nuclei with a large amount of richly nourished protoplasm.

But it should be noted that, although the evolutionary processes in the Peronosporales have resulted in uninucleate eggs, these structures are not strictly homologous with the eggs of algæ. They are homologous only in the sense that the eggs of Volvox, Fucus, Vaucheria, Chara, and several other highly developed algæ are homologous. In these algæ the eggs have an ancestry from much simpler types of gametes, and relationships must be traced through these or perhaps through older forms of asexual spores. The oogonium of the higher Peronosporales has come through a series of cœnogametes of which Albugo Bliti represents a certain stage, but whose earlier forms must have been simpler. The primitive conditions probably had a structure comparable to the cœnogametes of the Mucorales, and that type of structure finds its nearest approach among the algæ in the gametangia that discharge numerous gametes, as illustrated by Cladophora and many of the Siphonales.

But it will immediately be asked: What are we to do with such algal types as Vaucheria, Sphæroplea, Edogonium, etc. ? Have they no relation to the fungi? This will be considered under the topic "Phylogeny of the Phycomycetes and Ascomycetes." It is important that we emphasize now the evolutionary process brought out by 
Stevens's work on the four species of Albugo, and extend the results of that study to the Peronosporales as a whole. Accordingly, we have good reason to believe that the uninucleate eggs of Albugo candida, Peronospora, and Pythium have not been derived from the eggs of algal ancestry, but from cœnogametes which passed through the stage illustrated by Albugo Bliti, and came from much simpler conditions, probably resembling in many respects the cœnogametes of the moulds and Pyronema.

An origin of the simplest types of cœnogametes (moulds and Pyronema) from gametangia of algæ presents certain difficulties that should be discussed. The process would involve a change in the activities of a structure from one where the nuclei show a considerable degree of independence to one in which the nuclei co-operate in a cœnocytic cell that acts as a unit. An evolutionary process comparable to the above must have taken place with the development of the multinucleate zoospore of Vaucheria if its nuclei stand for the numerous zoospores generally formed in the terminal sporangia of the Siphonales. And a similar evolution, as has been mentioned before, is shown in the development among the Peronosporales of conidia (which germinate by tubes) from sporangia (conidia) that form zoospores. Such conidia and the zoospores of Vaucheria are not considered the equivalent of tissues, but units in their physiological behavior, just like uninucleate spores.

Similarly, the cœnogamete is not the equivalent of a tissue, and must not be considered as made up of independent gametes associated together because their cytoplasm is fused into a common mass. It exhibits the same sort of individuality as any cœnocytic cell or structure. We no longer draw sharp lines between uninucleate and multinucleate cells, for we realize that the transformation of the first into the second is a very simple matter, and that the unity of the cœnocyte is not disturbed by its having several or many nuclei, for these do not occupy fixed positions in the cell, but wander with the varying movements of the protoplasm. The cœnogamete is as much an individual cell as the uninucleate gamete, and distinctions can no more be drawn between these two structures than between the adjacent uninucleate and multinucleate cells of many plants (Chara, Rhodophyceæ, etc.). In view of its structure and behavior the term "cœenogamete" seems to the writer appropriate.

\section{PYRONEMA AND CENOGAMETES AMONG THE ASCOMYCETES}

Harper's (1900) investigation of Pyronema has established a condition in the Ascomycetes very similar to that among the Phycomycetes. Pyronema has as conspicuous a conogamete as the Mucorales or Albugo Bliti. Its peculiarities do not affect the essential cytological structure of the fusing multinucleate masses of protoplasm whose gamete nuclei unite in pairs as in Albugo Bliti and probably in the moulds. The sexual apparatus of Pyronema differs from the moulds chiefly in the development of that specialized structure the conjugating tube (trichogyne). This organ is manifestly of advantage because it affects a union with the antheridium and probably, as Harper suggests, represents the same sort of outgrowth from a sexual element as a 
trichogyne. The nuclei in the conjugating tube break down, and the structure finally becomes merely the channel through which the protoplasm from the antheridium flows into the oogonium. This movement of the protoplasm is very similar to Albugo Bliti, and the resemblance is carried still farther in the distribution and fusion of the gamete nuclei in pairs throughout the oogonium. The "receptive papilla" of Albugo is developed from the oogonium, and the conjugating tube in Pyronema may be considered an elaboration of such a growth tendency. Periplasm is lacking in Pyronema, but the mass of nucleate protoplasm that passes into the conjugating tube may relieve the oogonium of those conditions that result in the extensive degeneration of potential gamete nuclei in Saprolegnia or the somewhat similar conditions affected by the differentiation of a periplasm in the Peronosporales.

It is not to be supposed that the cœnogametes of Pyronema are closely related to those of the Mucorales or the Peronosporales, excepting as all of these structures are the homologues of gametangia. But it is important that we should recognize this condition among the Ascomycetes as one that further study may show to be not uncommon in the group. Juel (1902) reports it for Dipodascus. Miss Nichols's (1896) studies on Ceratostoma, while inconclusive in cytological details, are of importance in this connection. She has described and figured multinucleate oogonia (archicarps) and antheridia, which are said to fuse. They are apparently ccenogametes, and it is probable that these structures will be found in other genera of the Pyrenomycetes and Discomycetes. There are several forms whose archicarps suggest a cœnocytic structure (Eremascus, Ascobolus, Sordaria, Erotium, etc.).

The student of the homologies and evolution of the sexual organs among the Ascomycetes now finds himself face to face with the same problem that has been presented to Stevens and myself for the Phycomycetes. What is the relation of the uninucleate gamete (e.g., Sphærotheca) to the multinucleate? Which condition is the more primitive?

There is likely to be some confusion of homologies among the sexual organs of the Ascomycetes. The oogonium (archicarp) of Sphærotheca is morphologically a gametangium, and so is the antheridium, but both structures are physiologically gametes. The oogonium and antheridium of Pyronema are morphologically gametangia, so that in comparing these two forms we are dealing with homologous structures. Of course, we use them merely as illustrating certain sexual conditions; indeed, they are almost the only Ascomycetes whose sexual organs have been thoroughly studied, with the exception of certain lichens and the Laboulbeniaceæ, where the conditions are very different and which will be considered later.

The problem then will be: Did the uninucleate condition of the gametangium, as represented by Sphærotheca, come from a multinucleate gametangium (cœnogamete) illustrated by Pyronema, or is it the progenitor of the latter? We have no series of forms in the Ascomycetes such as the four species of Albugo studied by Stevens to help us to a conclusion. But the problem in the Ascomycetes seems to be identical 
with that of these Phycomycetes discussed in the previous sections of this paper. To derive a multinucleate gamete (Pyronema) from a uninucleate (Sphærotheca) involves an evolutionary process quite unknown to botany. To derive a uninucleate gamete from a cœnogamete merely demands a gradual reduction of the number of gamete nuclei, a process which we know to have taken place in several groups of algæ, independently of each other, and which is so beautifully shown in Stevens's series of four species of Albugo.

Harper $(1900$, pp. 388, 389) seems to be undecided as to the developmental relation of conditions in Sphærotheca to such as are presented in Pyronema. He shows that the oogonium of Sphærotheca could easily be given the form of Pyronema by the development of the beak into a conjugating tube with some minor changes in the position of the antheridium. But he disregards the internal changes necessary to derive a cœnogamete from a uninucleate gamete. And at the end of the same paragraph he says: "Still I am inclined to believe that the reverse process has taken place and that the sexual apparatus with the trichogyne represents the more primitive type for the Ascomycetes." To the writer resemblances of form have very little value in such comparisons, and relationships must be traced through agreement in the details of protoplasmic activities. And again, as Harper points out, the general morphology of the Erysipheæ is much higher than that of Pyronema. But Professor Harper by his last statement has warded off criticism, and perhaps, with the evidence from Albugo and Saprolegnia before him, he will feel more certain, with the writer, that the cœnogamete when related to the uninucleate gamete always represents more primitive conditions.

And this conception has a very interesting relation to the possibility of deriving the trichogynes of lichens and the Laboulbeniacer from a primitive type of sexual organ that may have been a cœnogamete. Of course, there is no reason why a uninucleate gamete (archicarp) among the fungi might not develop a simple trichogyne, as has been done in the Rhodophycex, but the trichogynes of the lichens and the Laboulbeniaceæ are generally systems of cells quite distinct from the female gamete (carpogenic cell). These conditions are nowhere presented in the red algæ, and it is very difficult to understand how a uninucleate gamete could develop such elaborate structures. But taking the suggestion of Harper (1900) that the conjugating tube of Pyronema is an outgrowth similar to a trichogyne, there are presented possibilities of various elaborate structural developments, because the outgrowth has so much protoplasm and many nuclei to draw upon. The evolutionary tendency of a cœnogamete is to reduce the number of functional gamete nuclei, generally by the sacrifice of many, but these with accompanying cytoplasm are sometimes employed to advantage in developing structural adaptations. In the Peronosporales the advantage lies in the activities displayed by the periplasm in assisting to form the spore wall. Araiospora (Thaxter, 1896) utilizes the periplasm to develop a cellular envelope surrounding the egg. The conjugating tube of Pyronema is evidently a desirable specialization, 
insuring a union with the male organ. Perhaps the elaborate multicellular trichogyne is the result of similar activities on the part of archicarps that are or were coenogametes.

It is obvious that this possibility has very important relations to comparisons that have been made between the trichogynes of the Ascomycetes and those of the Rhodophyceæ. It is not easy to homologize these structures and it is difficult to conceive the evolution of any group of the Ascomycetes from the red algæ. The Laboulbeniaceæ exhibit certain strong resemblances in a general similarity of cell structure, but peculiarities confront one whenever the comparison is carried into details. Nevertheless a relation of this group to the Rhodophycere remains a possibility, although it can hardly be more than mere speculation until we have much greater cytological knowledge of sexual processes here and in other Ascomycetes.

But the coenogamete may be found widespread among the Ascomycetes which suggests a new point of view that is worth attention. It is possible that the conogamete may become recognized as a primitive type of sexual organ in the Ascomycetes, as the writer believes it to be for certain regions of the Phycomycetes (Mucorales, Saprolegniales, and Peronosporales). Perhaps the complex conditions of such highly specialized groups as the Erysipheæ, lichens, and Laboulbeniacere may be related to the peculiar activities and possibilities of diverse development in this interesting sexual cell, the cœnogamete. Sphærotheca may readily stand as the last step in a process of nuclear reduction. Pyronema certainly exhibits the tendency to utilize superfluous nuclei and protoplasm in developing that advantageous structure the conjugating tube. And possibly such tendencies might result in the production of the elaborate trichogynes of the lichens and Laboulbeniaceæ and in the latter group the structure that resembles the procarp of the red alga.

\section{PHYLOGENY OF THE PHYCOMYCETES AND ASCOMYCETES}

The reader of this paper has probably already noted that some standpoints have been taken at variance with the generally accepted ideas of relationships among the Phycomycetes and Ascomycetes, and of these groups to an algal ancestry. A protest is sure to be offered against the disregard of certain Phycomycetes and algæ in the attempt to derive the Mucorales, Saprolegniales, and Peronosporales from an ancestry with cœnogametes.

There are certain Phycomycetes much closer to the algæ than any of the groups mentioned above. Monoblepharis and Myrioblepharis (Thaxter, 1895) exhibit sexual organs, zoospores, and vegetative structure with striking resemblances in various particulars to such algæ as Vaucheria, Edogonium, and Sphæroplea. The homologies can hardly be questioned and will not be elaborated here. These fungi, and possibly some of the Leptomitaceæ, seem to be close to heterogamous (oosporic) algæ and may well have come from that region of the Thallophytes. The family Leptomitaceæ includes some very remarkable types which have been well described by Thaxter (1896). Their 
position must remain somewhat uncertain until we know the nuclear structure of the sexual organs, but the general morphology of some forms indicates a relationship to the Peronosporales. Araiospora (Thaxter, 1896) is likely to prove especially interesting as illustrating an activity of the periplasm, in forming a cellular envelope around the oospore, that is not shown in any other type and which has important bearings on the possibilities of the cœnogamete to develop tissues of considerable complexity.

But many difficulties present themselves when the Monoblepharidre are made a starting-point for a line of ascent to the Peronosporales, as is done by Trow (1901, pp. 306, 307) when he arranges a series Monoblepharis, Saprolegnia, Pythium, and Albugo (Cystopus). These forms are not so similar that close relationships are manifest either through morphology or ontogeny. The most favorable interpretation must grant that they are at present widely divergent and highly specialized types, even assuming that ancestral forms now extinct might have had more general characters. Such speculations are, of course, entirely justifiable, if they do no violence to developmental processes.

However, as has been shown, such an evolution must assume either that uninucleate gametes became multinucleate or that differentiated eggs (Monoblepharis) lost their high state of specialization and finally their entire individuality in the cœnogamete of the Peronosporales. Both processes are opposed to what we know has been the evolutionary history of sexual cells in several divergent and independent groups of algæ. We are called upon to accept a "subjective phylogeny" opposed to wellestablished cytological processes.

The situation is somewhat similar to that presented to the Brefeldian school with respect to the origin of the ascus from the sporangium of a mould. Harper has shown that the protoplasmic activities of sporogenesis in the sporangium and ascus are along entirely different lines with nothing in common. To the writer such differences in cytological processes completely outweigh conclusions from any series of types presented on a basis of general form resemblance. Form resemblance between the ascus and sporangium can have very little morphological value until it be accompanied by evidence satisfactorily explaining the differences of protoplasmic organization and behavior. And the elaborate phylogenetic structure built by Brefeld and his followers is sadly in need of a foundation, if not already a ruin. Form resemblance must be in complete sympathy with cytological conditions to have weight.

Trow (1901) has criticised a developmental line that the writer indicated in 1900, which, he states, is an attempt to derive Oomycetes from a Zygomycete-like ancestry and which he considers an example of "subjective phylogeny." I have carefully examined what was written in that paper (Davis, 1900, pp. 301-9), and, not finding any reference to specific phylogenetic ancestry, am compelled to suggest to Trow a more careful reading and citation of that article. I presented there suggestions for the developmental history of the sexual conditions in the Peronosporales from cœnogametes derived from the gametangia of algæ. These cœnogametes at a certain stage 
in the process of sexual differentiation would be similar to the sexual organs of the Mucorales. The moulds were used to illustrate a well-defined sexual condition, which is not at all suggesting that they are the ancestry of the Peronosporales (Oomycetes).

But the present investigation of Saprolegnia, together with Stevens's (1901) later studies on Albugo, have strengthened my faith in the suggestions of that former paper (Davis, 1900). The Mucorales, Saprolegniales, and Peronosporales are generally acknowledged to be closely related groups, but it seems probable that the affinities are only through the somewhat similar conditions of sexual organs derived from the cœnogametes of some common ancestry. There are many peculiarities of life-habits, life-histories, and methods of asexual reproduction. Of these three groups the Mucorales presents the simplest conditions of sexuality and illustrates most nearly the structure of the primitive conogamete. The Peronosporales and Saprolegniales are difficult to relate to one another, for the higher development of the cœenogamete is apparently progressing along divergent lines. In the Peronosporales the protoplasmic differentiation in the oogonium determines a centrally placed egg in an enveloping periplasm, for a single cœnocentrum dominates the process of oogenesis. In the Saprolegniales the ooplasm gathers by cleavage around a number of conocentra, and all the protoplasm passes into the resulting eggs. To the writer the second process seems less highly specialized than the first and the Saprolegniales lower than the Peronosporales with respect to sexual processes. But oogenesis in these two groups shows such marked differences in their evolutionary tendencies that the question of the relative level of each process has very little import.

The Saprolegniales are more difficult to understand in relation to a cœnogamete ancestry than the Peronosporales, because the many eggs without periplasm suggest at once the stage in heterogamy illustrated by Sphæroplea. However, the processes of oogenesis are probably very different in the two types. The egg origins of Saprolegnia have a great many potential gamete nuclei, and that stage indicates strongly the cœnogamete ancestry. By numerical reduction of the gamete nuclei the egg of Saprolegnia has proceeded to a point where it has almost ceased to be a cœnogamete, that condition only being presented in the bi- and tri-nucleate eggs.

It will be difficult for many to give up the idea that Vaucheria is not a suitable starting-point for the line of higher Phycomycetes. The chief objection is the incompatibility of the processes of oogenesis where a relationship demands agreement even in the details of cytology. We have only the accounts of Oltmanns (1895), Behrens (1890), and Klebahn (1892), which are not in complete agreement on some important points, and perhaps further study may reveal conditions that are only suspected. In considerations of this sort it is important to know the relation that Vaucheria bears to the algre as a whole. Although generally classed among the Siphonales, Vaucheria has little in common with that group excepting the cœnocytic thallus. It stands alone as the only heterogamous form (oosporic) in a very large assemblage characteristically isogamous. Generally taught as a type of the Siphonales, 
Vaucheria is not really representative of that group, which is much better illustrated by such forms as Codium, Bryopsis, or Penicillus. The affinities of Cladophora with the Siphonales are now better understood, and we see that this form, except for the septate thallus - whose cells are, however, multinucleate - has all the characters of the Siphonales. It is this region of the algæ (Cladophora, Codium, etc.) that presents to the writer's mind conditions most nearly like the ancestry of the Mucorales, Saprolegniales, and Peronosporales, that is, an ancestry whose sexual organs were cœnogametes. However, perhaps, farther studies on the oogonium of Vaucheria may bring this structure into sympathy with cœenogametes.

The cœnogamete among the fungi must have come through the homologous structure among the algæ, the gametangium. We cannot suppose that such gametangia were highly specialized. It is hardly possible that they were heterogamous, for a highly differentiated oogonium would not be likely to return to conditions as simple as the primitive cœnogamete. The gametangia of such insogamous algre as Cladophora and Codium present most nearly the structure demanded of the progenitors of the primitive cœnogamete, but, of course, these forms are mentioned only as illustrations of conditions undoubtedly present in many groups of algæ at various periods in their evolutionary history.

We can only speculate as to the manner in which a gametangium might become a cœnogamete. The writer has already offered some suggestions on this point (Davis, 1900 , p. 308), and he is more inclined to them since the recent studies of Harper (1900) and Stevens (1901) and the present investigation of Saprolegnia. We can readily conceive the derivation from isogamous algæ of groups of aquatic fungi with terminal sporangia discharging motile gametes after the manner of Cladophora. Should such fungi leave the water and adopt a terrestrial life either as saprophytes (Mucorales) or parasites (Peronosporales), certain changes in the sexual processes would be very likely to result. The gametangia could not form and discharge motile gametes excepting when wet, and would be compelled to adapt themselves to the aërial environment. They would be very likely to develop such unity of structure and behavior as is displayed in Pythium and Peronospora by those sporangia (conidia) which have given up the habit of forming zoospores and now germinate by a tube. The gametangium would become a cœnocytic unit with the chemotactic qualities and possibilities associated with sexuality. These chemotactic influences might be satisfied by the fusion of the gametangia (ccenogametes) in pairs whereby the gamete nuclei would be able to unite two by two in a common protoplasmic medium. This process would take the place of the conjugation of motile gametes in water, and apparently satisfy all the hereditary demands as far as nuclei are concerned. The structure resulting from the fusion of these simplest cœnogametes would be very similar to the zygospore of the moulds.

Although there are no cœnogametes among the algæ, the sexual processes in the Conjugales have some features worth noting in this connection. In the desmids the 
gametes slip from the parent cells and fuse as naked masses of protoplasm. But in the filamentous forms Zygnemaceæ and Mesocarpaceæ the energids (gametes) remain in the respective parent cells which push out conjugating processes. The conjugating processes are surrounded by a cell wall so they are in every respect similar to the conjugating tube of Pyronema or the receptive papilla of the Peronosporales, excepting that they emanate from a uninucleate cell instead of a coenocyte. It is important to note that such conjugation processes in the Phycomycetes and Ascomycetes have their analogies in the algæ, for it might be suggested that the development of such a structure by a cœnogamete would be difficult. On the contrary, it seems the natural expression of any cell, whether uninucleate or multinucleate, with chemotactic tendencies to fuse with its neighbors. It is very probable that the development of such a conjugating tube in a cœnogamete would be at the point where formerly the naked motile gametes were discharged, for that place is evidently the seat of important cytoplasmic activities.

To sum up our conception of the Phycomycetes, we must, regard them as a group of several independent phyla. The Chytridiales in morphology and life-histories are the lowest and resemble the alga at the level of the Protococcales. Monoblepharis, and probably several other isolated genera, seem most closely related to heterogamous algx. The Entomophthorales are too highly specialized to be easily derived directly from algal ancestry and need not be considered in this paper. There are left the most conspicuous of the Phycomycetes in three orders that agree primarily in having either typical cœnogametes (Mucorales) or sexual organs probably derived from cœenogametes (Peronosporales and Saprolegniales).

These three orders can, however, only be related to one another through a common ancestry whose sexual organs were coenogametes. The Mucorales illustrate most completely the primitive cœnogamete, and for this reason in part may be considered rather the lower of the three groups. In the Peronosporales we have an ascending series from forms such as Albugo Bliti and A. Portulacae with true conogametes, although more highly specialized than those of the moulds, to the conditions in Albugo candida, Peronospora, and Pythium. This advance is evidently such an evolution as would provide a single uninucleate egg with the richest supply of food and best protective walls possible. In the Saprolegniales the evolutionary trend is similar in that a great many potential gamete nuclei are sacrificed to give a uninuclete egg, but we are not yet prepared to trace exactly the steps in the origin of this oogonium. However, the probabilities are that it, too, has come from a cœnogamete, and that the segmentation of this protoplasm to form many eggs does not imply a derivation from heterogamous ancestry, but special peculiarities associated perhaps with the presence of several cœnocentra. Oogenesis in Saprolegnia certainly indicates an ancestry with conogametes. The Mucorales, Peronosporales, and Saprolegniales then probably come from a s̊omewhat similar ancestry with cœnogametes, which necessitates their derivation from isogamous algæ at about such a level as is illustrated today by Cladophora and forms of the isogamous Siphonales. 
We do not propose to discuss the phylogeny of the Ascomycetes further than to present its problem with respect to the cœenogametes. The difficulty of relating the diverse sexual organs represented by Sphærotheca, Pyronema, the lichens, and the Laboulbeniacex has led to suggestions that the Ascomycetes are polyphyletic. But this view has many objections in the essential unity of the ascocarps and general rhythm of the life-histories throughout the group. Nevertheless, the various types of sexual reproduction seem very diverse when compared with one another and with conditions in the algæ and other fungi.

However, should the coenogamete be established as a primitive type of sexual organ here as in the Phycomycetes certain difficulties will be removed. The oogonium (archicarp) would be considered a development from the cœnogamete along a well-established evolutionary line, that of numerical nuclear reduction. The evolutionary trend of the cœnogamete would then be toward the uninucleate oogonium (Sphærotheca) following the tendency of sexual evolution so well recognized in the algæ. The groups of the Discomycetes and Pyrenomycetes would then readily arrange themselves according to the structure of the ascocarp and general vegetative complexity.

There would be left the lichens and Laboulbeniacer, whose trichogynes at least suggest the Rhodophyceæ, while in the latter group there are certain histological resemblances to this same group of algæ. Granting these possible affinities, it is nevertheless very difficult to conceive the multicellular trichogyne as derived from the simple structure of the red algæ. It must also be borne in mind that the structure of the ascocarp, especially among the lichens, gives no suggestion of a cystocarp, but, on the contrary, presents a structure identical with the fructification of other Ascomycetes. Were it possible for the cœnogamete to develop a multicellular trichogyne (there is a multinucleate one in Pyronema), then evolutionary lines might be established that would lead very naturally into the lichens and Laboulbeniaceæ. Such trichogynes would be another form of expression of this remarkable structure, the cœnogamete, which is able to utilize superfluous protoplasm in such a variety of ways.

In this connection it is interesting to sum up the various ways in which the superfluous protoplasm of a conogamete may assert itself. It may form a periplasm of importance in developing the spore wall (Peronosporales). It may form a surrounding tissue from such periplasm (Araiospora). It may develop a conjugating tube (Pyronema). And finally we suggest the possibility of multicellular trichogynes derived from cœnogametes. While this cannot be more than a speculation, nevertheless cytological and developmental investigations among the lichens and Laboulbeniacer in relation to these possibilities are sure to bring forth interesting results.

We may then conceive the Ascomycetes as presenting two important evolutionary lines derived from a primitive cœnocytic type of sexual organ (cœnogamete). The first, through numerical reduction of potential gamete nuclei, results in uninucleate sexual organs (Sphærotheca). The second line supposes the utilization of such potential gamete nuclei with cytoplasm to develop such secondary sexual structures as the 
conjugating tube of Pyronema and the trichogynes and procarpic apparatus of the lichens and Laboulbeniaceæ.

It is difficult to relate the account of Juel (1902) for Dipodascus to conditions in other cœnogametes. Juel believes that there is but one sexual nucleus in each of these multinucleate gametes, the others being "vegetative": that there is only one fusion nucleus in the fusion cell. This gives rise to a series of nuclei around which the spores develop in the sac and the "vegetative" nuclei degenerate. The details of the nuclear activities are not reported, and many stages in the processes are completely lacking. Until we know these we must hesitate to express an opinion on the position of Dipodascus.

\section{THE NUCLEUS OF PHYCOMYCETES IN ONTOGENY}

A detailed and complete study of the nucleus of some Phycomycetes in the various phases of ontogeny is greatly to be desired. At present we know a good deal about the nuclear activities during gametogenesis and something at the time when the oospore germinates, but the data are not complete for any one form and do not explain the most important problems of ontogeny. These concern the significance of the mitoses in the gametangia, the relative numbers of chromosomes at different periods of ontogeny, and their bearing on the sequence of generations, which is not well understood in this group.

This knowledge will demand the study of one or more types with attention to nuclear phenomena during vegetative periods, especially at the time when asexual spores or conidia are formed, during gametogenesis and the mitoses following the fusion of sexual nuclei. Species of Albugo and Peronospora seem to offer the best material for these investigations. Pythium, although easy to cultivate and control, has nuclei so small as to be almost impossible for such details, and the same difficulties apply to the Mucorales and in part to the Saprolegniales, while in this latter group the complications of apogamy render the forms useless for these problems. Speculations on the reduction of chromosomes and the significance of various phases of outogeny in this group are almost futile until we have convincing and complete data for one or more types.

Whatever may be the significance of the mitoses in the gametangia, there is no proof that they are reducing divisions, and it is probable that they are only phylogenetic reminiscences. Stevens's observations that the nuclei in the second mitosis of Albugo are much weaker in kinoplasm are interesting, but it is very questionable whether such divisions are necessary steps in the physiological differentiation of gametes. The mitosis may have simply a phylogenetic relation and the lessened kinoplasmic content be merely the result of that decrease in the size of the nuclei characteristic of advanced periods of oogenesis in these plants.

Everything seems to point to the ooplasm as trophoplasmic in character, first from the gathering of substance around the conocentrum, and second from the effect 
of this structure on nuclei in the vicinity. Staining reactions confirm this conclusion, but it is not wise to lay too much stress on the effects of stains in objects so small as these. And for this reason the judgment that the gamete nuclei are weak in kinoplasm must be taken with caution. The nuclei are generally smaller, and the conditions are such that the majority of them must disorganize; but the reason for this run-down state must be chiefly the general nutritive conditions of the gametangium, and not the mitoses of that period.

Stevens $(1901$, pp. 238, 239) lays stress on that period of oogenesis in Albugo and Peronospora termed "zonation," when the nuclei often in mitosis move from the center of the oogonium to the periphery. He suggests "that the nuclei pass to the periphery to rid themselves of superfluous kinoplasm, possibly to prevent parthenogenetic development of the oosphere." This theory seems to the writer to suppose an order of events and degree of preformed specialization more intricate than the evidence warrants. It seems more likely that "zonation" represents an event that happens to accompany, but is secondary to, those processes which gather the ooplasm in the center of the oogonium and give the egg its cœnocentrum and characteristic alveolar structure.

Indeed, the conditions that cause that extraordinary degeneration of nuclei in the oogonium must furnish in large part the solutions of these problems. This phenomenon is universal whether the nuclei break down in the eggs themselves (Saprolegniales) or are relegated to such secondary sexual structures as periplasm (Peronosporales) or a conjugating tube, as in the Ascomycete Pyronema. As we have seen in Saprolegnia, the many nuclei in the eggs during advanced stages of oogenesis are all much reduced in size, and the only thing that saves the fortunate survivors of the generally severe conditions is proximity to that center of metabolic activity, the cœnocentrum. There is a limit to the number of nuclei possible in a given amount of cytoplasm. The nutrition of the oogonium decreases as oogenesis proceeds, and finally reaches a point when the nuclei are sorely pressed to maintain themselves. This certainly seems to be the history for the Saprolegniales, and probably every Phycomycete whose sexual organs are cœnogametes, as these structures are generally formed late in ontogeny when the period of vegetation is about completed.

The nuclei are then subjected to a keen struggle for existence, and, in spite of the fact that they are in a symplast, which is itself a unit, they may well be supposed each to look after its own interest as far as possible. The outcome of that struggle is largely determined by the activities of the cytoplasm, which may develop such metabolic centers (morphologically expressed by cœnocentra) that certain nuclei by good fortune of favorable position are given great advantages over their neighbors and finally selected as the survivors.

There are a number of instances known where structures sacrifice some of their nuclei to provide the remainder with the cytoplasm at hand. Certain of the Fucales are notable examples, and there will probably be found other illustrations among the 
algre and fungi. Analogous conditions in animals have been reported, as in oogenesis of Actinosphæria (Hertwig, 1898), and the well-known fate of supernumerary male nuclei in polyspermy. In these cases there has not been reported the same close relation between the surviving nuclei and metabolic centers of the cell as between the favored nuclei and the conocentra of the Saprolegniales and Peronosporales. In this same connection we need more detailed accounts of oogenesis in the Fucales, Vaucheria and Sphæroplea.

The reasons why the oogonium overstocks itself with nuclei are probably phylogenetic and recall the time when numerous uninucleate gametes were formed from the protoplasm that now acts as a unit (cœnogamete). Such uninucleate gametes were probably smaller than their homologues, the asexual zoospores, as is so characteristic of algæ. Among the algæe it is generally conceded that the small gamete swarm spores result from different conditions of nourishment than their asexual homologues. It has been suggested that they are starved, but that seems a clumsy conception of very intricate processes. But there must be deep significance in the overproduction of sexual nuclei during gametogenesis and its obvious association with the deficient nutrition at the command of the gametangia. This phase of the subject has not received the attention it deserves.

\section{SUMMARY OF THE INVESTIGATION OF SAPROLEGNIA}

\section{OOGENESIS}

The material, Saprolegnia mixta, was apogamous, being entirely free from antheridial filaments.

The resting nucleus has a loose linin network and a nucleolus, and presents essentially the structure of the nucleus of higher plants.

There is one mitosis in the oogonium, the spindle being intranuclear. There are no centrosomes. The four chromosomes are derived from the linin network.

The daughter-nuclei following the mitosis are much smaller than their parents. They shortly give evidence of coming degeneration, the nuclear membranes become indistinct, and the contents finally lie as granular material in clear areas resembling vacuoles.

The eggs are formed during the process of nuclear degeneration. The protoplasm in the oogonium at this period is arranged peripherally around a large central vacuole. The ooplasm collects around several centers, each of which is to become an egg origin. The egg origins are finally separated through the arrangement of vacuoles which results in the severance of connecting strands of protoplasm, and the eggs round themselves off as independent structures.

The differentiation of the egg origins takes place around a deeply stained protoplasmic body, the cœnocentrum, from which delicate fibrillæ radiate. The cœnocentrum is formed de novo, one for each spore origin. It is at first a small globule, made conspicuous, however, by its fibrillar rays. It is most conspicuous in the young eggs, 
becoming less distinct with the ripening, and finally disappears. There is no trace of it in the oldest eggs.

The cœnocentrum is a protoplasmic structure, but not a permanent organ of the cell. It is probably the morphological expression of dynamic activities in the oogonium when the egg origins are differentiated, and is a sort of focal point of the metabolic processes peculiar to oogenesis.

The conocentrum exerts a chemotactic influence on any nuclei in its immediate vicinity. Generally one nucleus is selected and comes to lie very close to the cœnocentrum, so that these two structures in the egg origins may be separated only under high magnification. This nucleus increases in size when all other nuclei in the egg origins and young eggs are degenerating, showing that it is greatly favored with respect to nourishment by its position near the cœenocentrum.

Sometimes two or even three nuclei may lie sufficiently near the cœnocentrum to be saved from degeneration, and such eggs are in consequence bi- or trinucleate. Binucleate eggrs are not uncommon, trinucleate eggs are more rare.

As the eggs mature, the favored nucleus increases greatly in size, until it is many times larger than at the period following the mitosis. The other nuclei have generally completely disorganized, but sometimes traces remain as granules scattered in the cytoplasm.

Binucleate eggs in the Saprolegniales need have no relation to the problem of sexuality, and Trow's conclusions are not established.

\section{SPOROGENESIS}

A general confirmation of the accounts of Rothert, Hartog, and Humphrey.

The uninucleate spore origins are differentiated by clefts that push their way from the central vacuole of the sporangium to the periphery. When the clefts reach the cell wall, the turgor of the sporangium is relieved through the escape of water, and the spore origins run together, but they soon draw apart and round themselves off as zoospores. There seem to be no cytoplasmic centers in the sporangium comparable to the cœulocentra.

\section{LITERATURE CITED}

Behrexs. "Einige Beobachtungen über die Entwickelung des Oogons und der Oosphäre von Vaucheria." Ber. d. deut. bot. Gesell., Vol. VIII (1890), p. 314.

Davis. "The Fertilization of Albugo candida." Bot. Gaz., Vol. XXIX (1900), p. 297.

Golenkrn. "Ueber die Befruchtung bei Sphaeroplea annulina und über die Structure der Zellkerne bei einigen grünen Algen.” Bull. Soc. Imp. Nat. Moscow, 1899, p. 343.

Grober. "Ueber das Verhalten der Zellkerne in den Zygosporen von Sporodinia grandis, Link." Ber.d. deut. bot. Gesell., Vol. XIX (1901), p. 51.

HARPER. "Sexual Reproduction in Pyronema confluens and the Morphology of the Ascocarp." Ann. of Bot., Vol. XIV (1900), p. 321. 
Hartog. "Recent Researches on the Saprolegniaceae: A Critical Abstract of Rothert's Results." Ibid., Vol. II (1888), p. 201.

"Some Problems of Reproduction." Quar. Jour. of Mic. Sci., Vol. XXXIII (1891).

"On the Cytology of the Vegetative and Reproductive Organs of the Saprolegnieae."

Trans. Roy. Irish Acad., Vol. XXX (1895), p. 645.

"The Cytology of Saprolegnia." Ann. of Bot., Vol. X (1896), p. 98.

"The Alleged Fertilization in the Saprolegnieae." Ibid., Vol. XIII (1899), p. 447.

HERTwia. "Ueber Kerntheilung, Richtungskörperbildung und Befruchtung von Actinosphaerium eichorni." Abhand. bayer. Akad. Wiss., Vol. XIX (1898).

Humphrex. "The Saprolegniaceae of the United States, with Notes on Other Species." Amer. Phil. Soc., 1892.

JoEx. "Ueber Zellinhalt, Befruchtung und Sporenbildung bei Dipodascus." Flora, Vol. XCI (1902), p. 45.

Krebahn. "Studien über Zygoten; II: Die Befruchtung von Oedogonium Boscii." Jahrb. f. wiss. Bot., Vol. XXIV (1892), p. 235.

"DieBefruchtung von Sphaeroplea annulina Ag." Festschrift für Schwendener, 1899, p. 81.

KLEBS. "Zur Physiologie der Fortpflanzung einiger Pilze; II: Saprolegnia mixta." Jahrb.f. wiss. Bot., Vol. XXXIII (1899), p. 71.

Mrтzkewitscr. "Ueber die Kerntheilung bei Spirogyra." Flora, Vol. LXXXV (1898), p. 81.

Mixake. "The Fertilization of Pythium de Baryamum." Ann. of Bot., Vol. XV (1901), p. 653.

Nichols. "The Morphology and Development of Certain Pyrenomycetous Fungi." Bot. Gaz., Vo]. XXII (1896), p. 301.

Outmanns. "Ueber die Entwickelung der Sexualorgane bei Vaucheria." Flora, Vol. LXXX (1895), p. 388.

Rothert. "Die Entwickelung der Sporangien bei den Saprolegnieen." Cohn's Beiträge z. Biol.d. Pflan., Vol. V (1888), p. 291.

Ruhland. "Die Befruchtung von Albugo lepigoni und einigen Peronosporaceen." Hedwigia, Vol. XLI (1902), p. 179.

Stevens. "The Compound Oosphere of Albugo bliti." Bot. Gaz., Vol. XXVIII (1899), p. 149. "Die Gametogenese und Befruchtung bei Albugo." Ber. d. deut. bot. Gesell., Vol. XIX (1901), p. 171.

"Gametogenesis and Fertilization in Albugo." Bot. Gaz., Vol. XXXII (1901), p. 77.

"Studies in the Fertilization of Phycomycetes: Sclerospora." Ibid., Vol. XXXIV (1902), p. 420 .

Strasburger. "Schwarmsporen, Gameten, pflanzlichen Spermatozoiden und das Wesen der Befruchtung." Hist. Beiträge, Vol. IV (1892), p. 48.

Thaxter. "New or Peculiar Aquatic Fungi; I: Monoblepharis." Bot. Gaz., Vol. XX (1895), p. 433.

"New or Peculiar Aquatic Fungi; II: Gonopodya Fischer and Myrioblepharis nov. gen."

Ibid., p. 477.

"New or Peculiar Aquatic Fungi; III: Blastocladia." Ibid., Vol. XXI (1896), p. 45.

"New or Peculiar Aquatic Fungi; IV: Rhipidium, Sapromyces, and Araiospora." Ibid., p. 317.

Timberlake. "Development and Structure of the Swarmspores of Hydrodictyon." Trans. Wis. Acad. Sci. Arts and Letters, Vol. XIII (1902), p. 486.

Trow. "The Karyology of Saprolegnia." Ann. of Bot., Vol. IX (1895), p. 609.

"Observations on the Biology and Cytology of a New Variety of Achlya Americana." Ibid., Vol. XIII (1899), p. 131.

"Biology and Cytology of Pythium ultimum." Ibid., Vol. XV (1901), p. 269. 
WAGER. "Observations on the Structure of the Nuclei of Peronospora parasitica." Ibid., Vol. IV (1889), p. 127.

"On the Structure and Reproduction of Cystopus candidus Lev." Ibid., Vol. X (1896), p. 295.

"On the Fertilization of Peronospora parasitica." Ibid., Vol. XIV (1901), p. 263.

Wisselingh. "Ueber Kerntheilung bei Spirogyra." Flora, Vol. LXXXVII (1900), p. 355.

\section{EXPLANATION OF PLATES}

The material, fixed in weak chrom-acetic acid, was cut $3 \mu$ thick and stained on the slide with safranin and gentian violet. All figures were sketched with an Abbe camera under the Zeiss apochromatic objective $2 \mathrm{~mm}$. aper. 1.30 , or $1.5 \mathrm{~mm}$. in combination with compensating oculars. The magnification is as follows: Fig. 1, 250 diameters; Figs. 2-5, 12, and 13, 500 diameters; Figs. 6-9, 1,500 diameters; Figs. 10, 11, and 14-29, 1,000 diameters; Figs. 30-35, 667 diameters.

\section{PLATE XV}

(Figs. 1-15 illustrate Oogenesis)

Fis. 1.-End of hypha about to form an oogonium.

Fia. 2.-Young oogonium, nuclei approaching spirem.

Fig. 3.-Central vacuole forming.

FIG. 4.-Central vacuole; nuclei in spirem.

Fiq. 5.-More advanced than Fig. 4; nuclei in mitosis.

Fig. 6.-Details of nucleus in spirem condition.

FiG. 7.-Metaphase of mitosis; spindle intranuclear; nucleolus outside of spindle; three chromosomes shown.

Fig. 8.-Mitosis just after the splitting of chromosomes at nuclear plate; nucleolus outside the spindle.

FIG. 9.-Anaphase; two groups of chromosomes, four in each group, at the poles.

Fig. 10.-Oogonium after mitosis with twice as many nuclei as previous to that event.

FIG. 11.-Oogonium older than in Fig. 10; nuclei degenerating.

Fig. 12.-Formation of egg origins under low magnification (500 diameters); cœnocentrum in center of each egg origin.

FIG. 13.-Egg origins older than in Fig. 12; cœnocentra with conspicuous radiations.

Fia. 14. - Coenocentrum before the differentiation of the egg origins; radiations plain; nucleus at one side of cœenocentrum; other nuclei degenerating in the cytoplasm.

Fig. 15. - Similar to Fig. 14; two coenocentra; nucleus at the side of each; many nuclei degenerating in the cytoplasm.

\section{PLATE XVI}

(Figs. 16-29 illustrate Oogenesis)

Fig. 16. - Egg origin just before rounding off to form egg; conspicuous conocentrum with nucleus at the side.

Frg. 17.- Young egg, nucleus larger than in Fig. 16.

Fig. 18.-Young egg; cœenocentrum without radiations.

Fig. 19.-Egg, older than in Figs. 17 and 18; nucleus larger.

Fig. 20.-Egg with nucleus extended toward cœnocentrum, which has almost disappeared.

Fig. 21.-Mature egg; large nucleus; cœnocentrum disappeared.

Fig. 22.- Young binucleate egg, the two small nuclei close to the smaller coenocentrum. 
Fig. 23.-Young egg with two cœenocentra, each accompanied by a nucleus.

FIG. 24.-An exceptionally large binucleate.egg with prominent conocentrum.

FIG. 25. -Egg with two nuclei lying over one another, both extended toward the coenocentrum.

FIG. 26.-Binucleate egg with the nuclei at a distance from one another.

FIG. 27.-Binucleate egg with the nuclei close together.

FIG. 28. - Trinucleate egg, the three nuclei lying close together.

FIG. 29.-Trinucleate egg, the three nuclei at a distance from one another.

(Figs. 30-35 illustrate Sporogenesis)

FIG. 30.--End of sporangium showing development of central vacuole.

FIG. 31. - Portion of cross section of sporangium, central vacuole well developed.

Fig. 32.-Early stage of segmentation; cleavage furrows running from central vacuole to periphery.

Fig. 33.-After cleavage furrows have reached periphery, spore origins forming.

Fig. 34.-Spore origins older than in Fig. 33.

FIG. 35.-Zoospores in sporangium. 


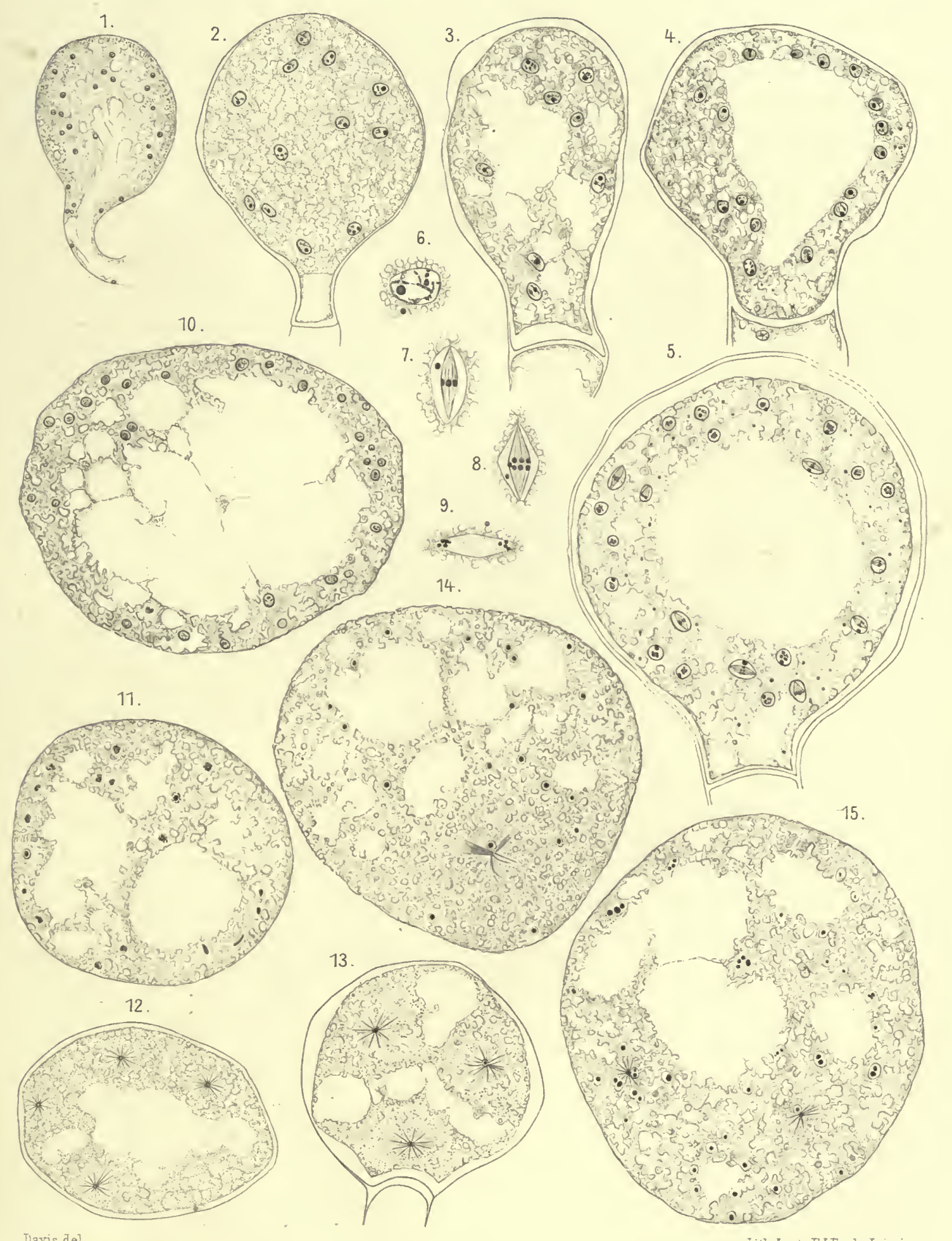

Davis.del. 


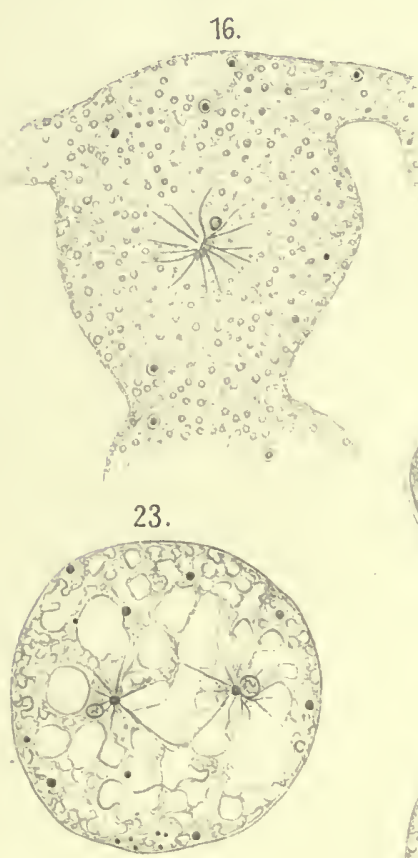

26.

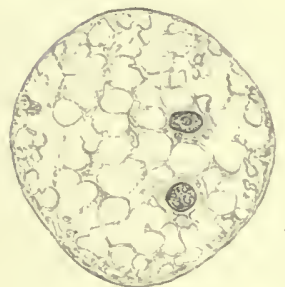

30.

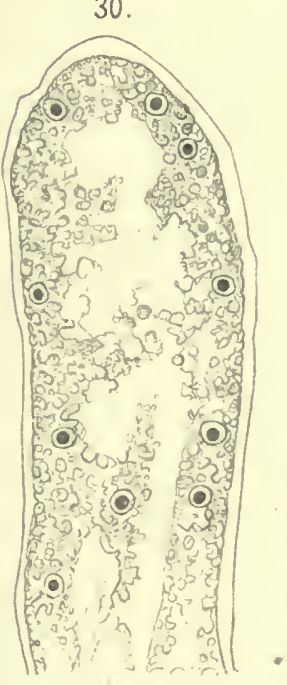

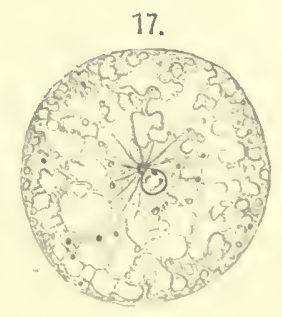

21.

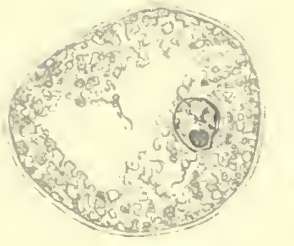

24.
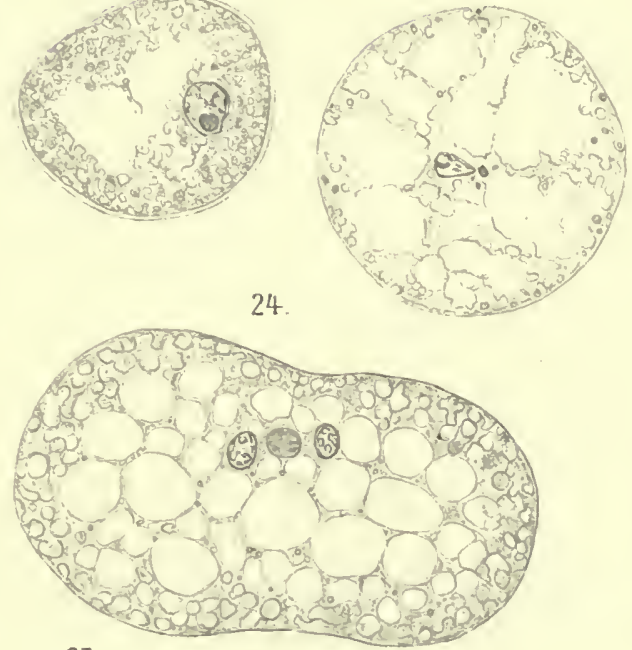

27.

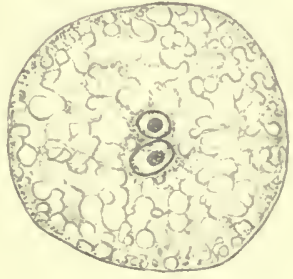

31.

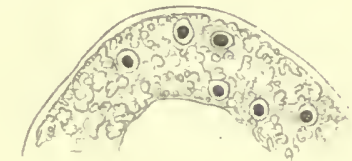

32.
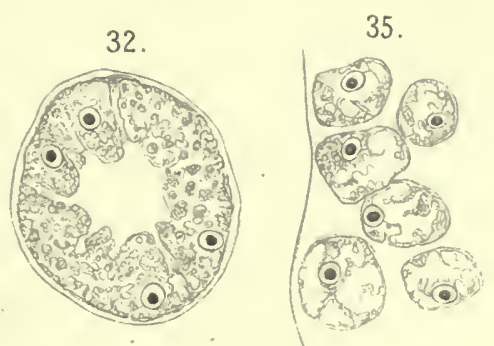

28.

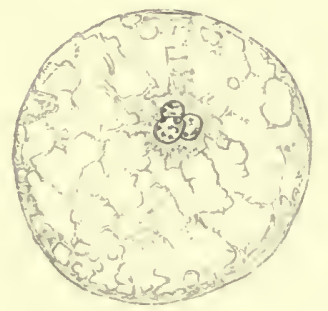

34.

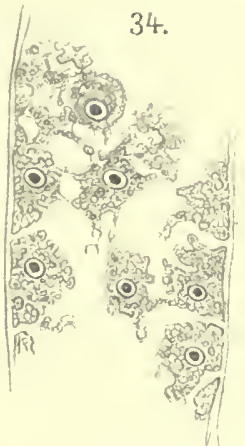

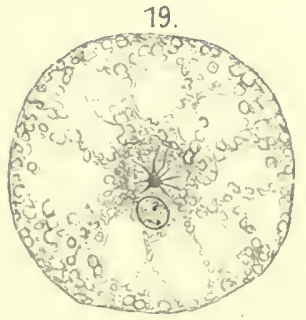

22

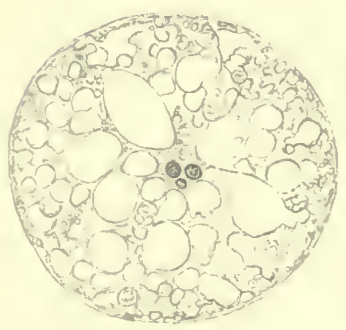

25.

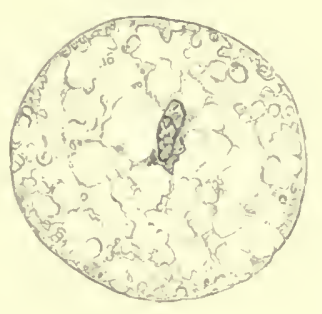

29.

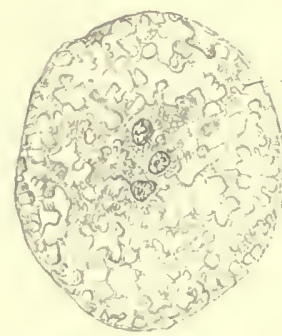

33.

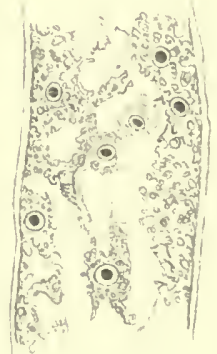

Davis del. 
 





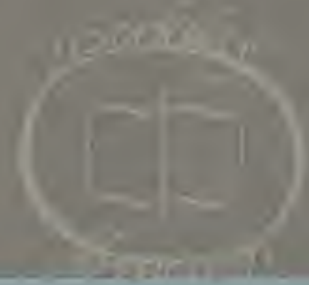

14 DAY USE

RETURN TO DESK FROM WHICH BORROWED

LOAN DEPT.

This book is due on the last date stamped below, or on the date to which renewed.

Renewed books are subject to immediate recall.

\begin{tabular}{|c|c|}
\hline JUN 24196687 & \\
\hline an $1066 \quad R C D$ & \\
\hline$A P R 301968$ & 15 \\
\hline RECEIVED & \\
\hline MAY $7 \cdot 6 \Omega$ - $16 \mathrm{AM}$ & \\
\hline LOAN DOTT. & \\
\hline MAY 21196995 & \\
\hline $\begin{array}{l}\text { RUID TO FARIH } \\
\text { SCIENCES LIB. }\end{array}$ & \\
\hline $\begin{array}{c}\text { JUN } 31969 \\
\text { REC'D LD } \\
\text { QPR } 519748.9\end{array}$ & JUN $4{ }^{\prime} 69-2$ PM \\
\hline $\begin{array}{l}\text { T } 21 A-60 m-10 \\
P 7763810) 47\end{array}$ & $\begin{array}{l}\text { General Library } \\
\text { University of California } \\
\text { Berkeley }\end{array}$ \\
\hline
\end{tabular}
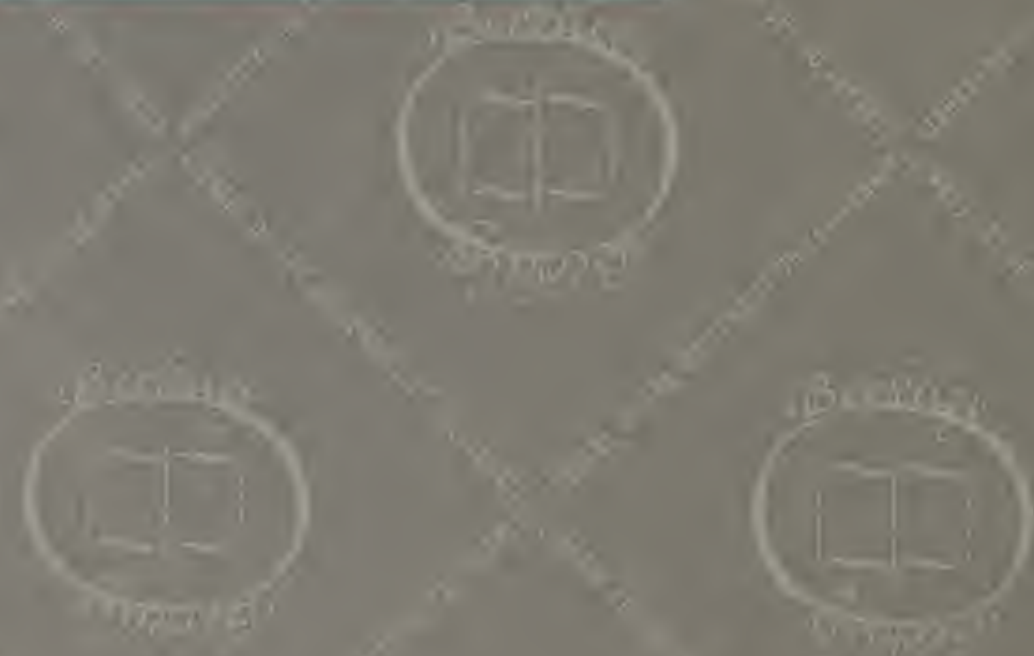


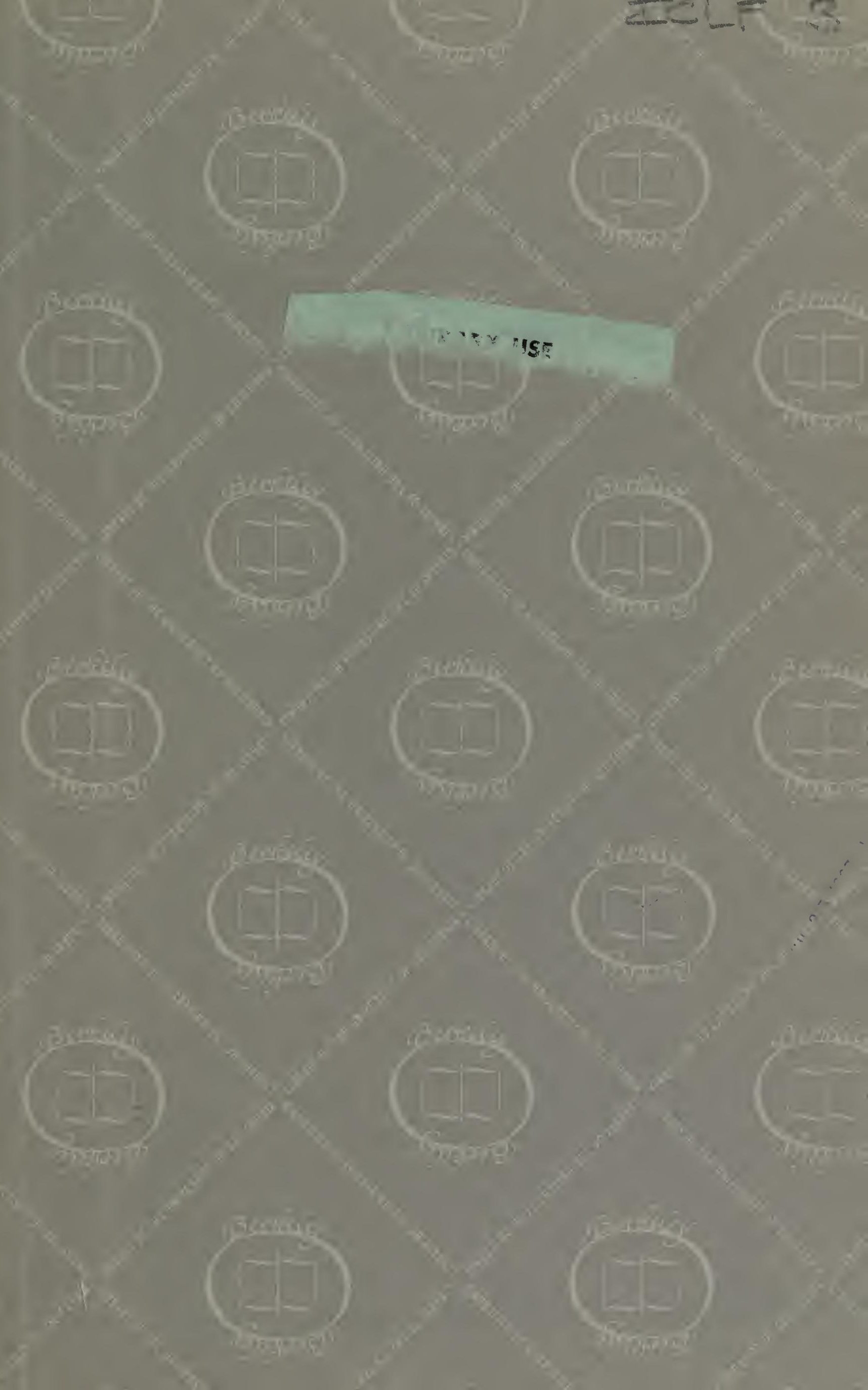


s.

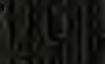

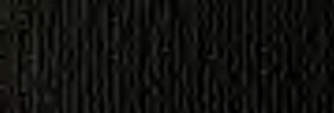

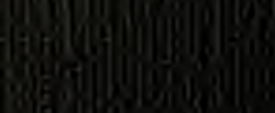

